\title{
Transfer of $\mathrm{IP}_{3}$ through gap junctions is critical, but not sufficient, for the spread of apoptosis
}

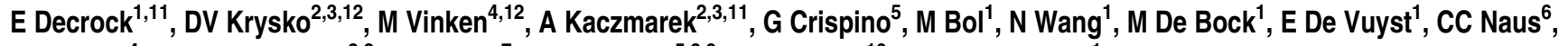 \\ V Rogiers ${ }^{4}$, P Vandenabeele ${ }^{2,3}$, C Erneux ${ }^{7}, F$ Mammano ${ }^{5,8,9}$, G Bultynck $^{10}$ and L Leybaert ${ }^{\star, 1}$
}

Decades of research have indicated that gap junction channels contribute to the propagation of apoptosis between neighboring cells. Inositol 1,4,5-trisphosphate $\left(\mathbb{I P}_{3}\right)$ has been proposed as the responsible molecule conveying the apoptotic message, although conclusive results are still missing. We investigated the role of $\mathrm{IP}_{3}$ in a model of gap junction-mediated spreading of cytochrome $C$-induced apoptosis. We used targeted loading of high-molecular-weight agents interfering with the $\mathrm{IP}_{3}$ signaling cascade in the apoptosis trigger zone and cell death communication zone of C6-glioma cells heterologously expressing connexin (Cx)43 or $\mathbf{C x 2 6}$. Blocking $\mathrm{IP}_{3}$ receptors or stimulating $\mathrm{IP}_{3}$ degradation both diminished the propagation of apoptosis. Apoptosis spread was also reduced in cells expressing mutant $\mathrm{Cx26}$, which forms gap junctions with an impaired $\mathbb{I}_{3}$ permeability. However, $\mathbb{I P}_{3}$ by itself was not able to induce cell death, but only potentiated cell death propagation when the apoptosis trigger was applied. We conclude that $\mathrm{IP}_{3}$ is a key necessary messenger for communicating apoptotic cell death via gap junctions, but needs to team up with other factors to become a fully pro-apoptotic messenger.

Cell Death and Differentiation (2012) 19, 947-957; doi:10.1038/cdd.2011.176; published online 25 November 2011

$\mathrm{Ca}^{2+}$ regulates a wide range of cellular processes, including cell death by apoptosis. It is highly compartmentalized in the cell and alterations in $\mathrm{Ca}^{2+}$ distribution induce and control apoptosis. ${ }^{1-3}$ The endoplasmic reticulum (ER) is the main intracellular $\mathrm{Ca}^{2+}$ store, and is critically involved in intracellular $\mathrm{Ca}^{2+}$ homeostasis and signaling. In many cases, pro-apoptotic $\mathrm{Ca}^{2+}$ elevation is mediated by inositol 1,4,5-trisphosphate $\left(\mathrm{IP}_{3}\right)$-induced channel opening with rapid mobilization of $\mathrm{Ca}^{2+}$ from the ER lumen into the cytosol. ${ }^{3,4} \mathrm{IP}_{3}$-linked $\mathrm{Ca}^{2+}$ signals may in turn trigger apoptosis by compromising mitochondrial function. ${ }^{1,5} \mathrm{Ca}^{2+}$ changes in a cell can be divided into different categories depending on the duration (transient versus sustained) or the pattern (oscillations versus waves) with sustained $\mathrm{Ca}^{2+}$ elevation resulting in cell death, while $\mathrm{Ca}^{2+}$ oscillations (repetitive spikes) are suggested to promote cell survival. ${ }^{6,7}$ $\mathrm{Ca}^{2+}$ signals can also be propagated from cell-to-cell as intercellular $\mathrm{Ca}^{2+}$ waves, based on both paracrine signaling and the diffusion of $\mathrm{IP}_{3}$ via gap junction channels (GJs). ${ }^{6,8}$
GJs are constructed by two opposing hemichannels, belonging to the membranes of adjacent cells. Hemichannels are composed of six transmembrane connexin (Cx) proteins, named according to their predicted molecular weight. ${ }^{9}$ GJs allow the passage of small and hydrophilic molecules $(<1.5 \mathrm{kDa})$ between the cytoplasm of neighboring cells, which provides them not only important physiological but also pathological functions. Moreover, GJs can control cell death/ survival by mediating the spread of pro- and anti-apoptotic molecules between cells. ${ }^{10}$ Previous work from our group as well as others demonstrated that cytochrome $\mathrm{C}$ (CytC)induced apoptosis propagates from dying to healthy neighboring cells through GJs. ${ }^{11-16}$ Further investigations toward the biochemical nature of the cell death messenger revealed that $\mathrm{Ca}^{2+}$ seems to play a pivotal role in this process. ${ }^{11,13,16,17}$ However, slowly mobile cytoplasmic $\mathrm{Ca}^{2+}$-binding proteins limit $\mathrm{Ca}^{2+}$ diffusion in the cytoplasm, making $\mathrm{IP}_{3}(\mathrm{MW} 420 \mathrm{Da})$, with a 20 times larger diffusion coefficient and 100 times larger

\footnotetext{
${ }^{1}$ Department of Basic Medical Sciences - Physiology group, Faculty of Medicine and Health Sciences, Ghent University, Ghent 9000, Belgium; ${ }^{2}$ Molecular Signalling and Cell Death Unit, Department for Molecular Biomedical Research, VIB, Ghent 9052, Belgium; ${ }^{3}$ Department of Biomedical Molecular Biology, Ghent University, Ghent 9052, Belgium; ${ }^{4}$ Department of Toxicology - Center for Pharmaceutical Research, Faculty of Medicine and Pharmacy, Vrije Universiteit Brussel, Brussels 1090, Belgium; ${ }^{5}$ Istituto Veneto di Medicina Molecolare, Fondazione per la Ricerca Biomedica Avanzata, Padova 35129, Italy; ${ }^{6}$ Department of Cellular and Physiological Sciences, Faculty of Medicine, University of British Columbia, Vancouver, BC, V6 T 1Z3, Canada; ${ }^{7}$ Institut de Recherche Interdisciplinaire et Biologie Humaine et Moléculaire (IRIBHM), Faculty of Medicine, Université Libre de Bruxelles, Brussels 1070, Belgium; 'Dipartimento di Fisica 'G Galilei', Universita' di Padova, Padova 35131 , Italy; ${ }^{9}$ Istituto CNR di Neuroscienze, Padova, Italy and ${ }^{10}$ Department of Molecular Cell Biology-Laboratory of Molecular and Cellular Signalling, Faculty of Medicine, Katholieke Universiteit Leuven, Leuven 3000, Belgium

${ }^{*}$ Corresponding author: L Leybaert, Department Basic Medical Sciences - Physiology group, Faculty of Medicine and Health Sciences, Ghent University, De Pintelaan 185 (Block B, third floor), Ghent 9000, Belgium. Tel: + 32933233 66; Fax: + 32933230 59; E-mail: Luc.Leybaert@ Ugent.be

${ }^{11} \mathrm{ED}$ and $\mathrm{AK}$ are doctoral research fellows of the Fund for Scientific Research Flanders (FWO-Vlaanderen), Belgium

${ }^{12} \mathrm{MV}$ and DVK are postdoctoral research fellows of the Fund for Scientific Research Flanders (FWO-Vlaanderen), Belgium

Keywords: apoptosis; calcium; connexin; inositol 1,4,5-trisphosphate; gap junction

Abbreviations: Al, apoptotic index; AUC, area under the curve; BH4-Bcl-2, BH4 domain of Bcl-2; BIND, a mutant BH4-Bcl-2 peptide in which the surface-accessible residues have been altered; $C b x$, carbenoxolone; $C x$, connexin; $C y t C$, cytochrome $C$; $\left[\mathrm{Ca}^{2+}\right]_{\mathrm{i}}$, cytoplasmic $\mathrm{Ca}^{2+}$ concentration; DAPI, $2^{\prime}, 6^{\prime}$-diamidino-2-phenylindole; DMEM, Dulbecco's modified Eagle's medium; DTR, dextran Texas Red; ER, endoplasmic reticulum; EV, empty vector; GJ, gap junction channel; HBSS-Hepes, Hanks' balanced salt solution buffered with Hepes; IDP, IP ${ }_{3} R$-derived peptide; $I_{3}$, inositol 1,4,5-trisphosphate; $I_{3} R$, inositol 1,4,5-trisphosphate receptor; NALC, $N$-acetyl Lcysteine; PBSD + , PBS supplemented with $\mathrm{Ca}^{2+}$ and $\mathrm{Mg}^{2+}$; PFA, paraformaldehyde; PI, propidium iodide; PLC, phospholipase C; PTP, permeability transition pore; ROS, reactive oxygen species; SCR, scrambled version of BH4-Bcl-2; SLDT, scrape loading and dye transfer; WT, wild-type

Received 10.8.11; revised 07.10.11; accepted 25.10.11; Edited by RA Knight; published online 25.11.11
} 
GJ permeability, a more suitable candidate..$^{8,18,19}$ Moreover, its $E R I P_{3}$ receptor $\left(I P_{3} R\right)$ channel is modulated by pro- and anti-apoptotic proteins, ${ }^{1,3,7,20,21}$ and the ensuing $\mathrm{Ca}^{2+}$ changes may trigger $\mathrm{Cyt} C$ release from the mitochondria. ${ }^{5}$

Here, we examined the role of $\mathrm{IP}_{3}$ in the communication of apoptosis from dying cells to surrounding healthy cells via GJs. Although this molecule is suggested to contribute to GJ-mediated spread of apoptosis, ${ }^{13}$ it remains unsolved whether $\mathrm{IP}_{3}$ diffusion via GJs is necessary and sufficient to provoke cell death in cells coupled by GJs. In this study, we aimed (i) to specifically interfere with $\mathrm{IP}_{3}$ generation in the cells in which apoptosis was induced (trigger cells) and also in recipient cells receiving the cell death message via GJs, (ii) to interfere with the $I P_{3} R$ in trigger and recipient cells and (iii) to interfere with the passage of $I P_{3}$ via GJs. Our results show that the cell death spreading process crucially relies on not only the GJ-mediated transfer of $\mathrm{IP}_{3}$ but also requires other factors to convert this physiological messenger into an intercellular master in crime.

\section{Results}

Interfering with $\mathrm{IP}_{3}$ signaling reduces the propagation of Cyt $\boldsymbol{C}$-triggered apoptosis. We loaded a small and defined zone of cells within confluent rat C6-glioma cultures, stably transfected with $\mathrm{Cx} 43$ (C6Cx43), with $100 \mu \mathrm{M}$ Cyt $C$ to induce apoptosis (trigger zone) combined with $100 \mu \mathrm{M}$ Dextran Texas Red (DTR) to identify the cells receiving the apoptotic trigger. Cell loading with these membrane-impermeable substances was performed by in situ electroporation that was optimized to avoid inducing cell death by itself. ${ }^{11}$ After $6 \mathrm{~h}$, significant apoptosis was detected in a $200 \mu \mathrm{m}$ wide zone adjacent to the trigger zone (communication zone; Figure 1a). We previously demonstrated that GJs predominantly mediate the communication of apoptosis to this area. ${ }^{11}$ To assess whether the $\mathrm{Ca}^{2+}$-mobilizing messenger $\mathrm{IP}_{3}$ and its ER-located receptor contribute to this process, we loaded membraneand GJ-impermeable compounds that interfere with $\mathrm{IP}_{3}$ signaling in the trigger or communication zone by in situ electroporation, and investigated their effect on cell death spread by quantifying apoptosis in the communication zone (Figure 1). As the agents applied are membrane and GJ impermeable, their action was limited to the loaded cell zone.

In a first set of experiments, we promoted $\mathrm{IP}_{3}$ degradation by loading the cells in the trigger or communication zone with a human type I $\mathrm{IP}_{3}$ 5-phosphatase (MW $43 \mathrm{kDa}$ ), which specifically hydrolyses the phosphate group on the fifth position of the inositol moiety. Two controls were applied, one containing no enzyme and one with inactivated enzyme. We first checked the activity of these substances by monitoring their effect on changes in cytoplasmic $\mathrm{Ca}^{2+}$ concentration $\left(\left[\mathrm{Ca}^{2+}\right]_{i}\right)$ triggered by photolytic release of $\mathrm{IP}_{3}$ from a caged inactive precursor (caged $\mathrm{IP}_{3}$ ). We found that the active $\mathrm{IP}_{3}$ 5-phosphatase (loaded together with caged $\mathrm{IP}_{3}$ in the same region) significantly suppressed the $\left[\mathrm{Ca}^{2+}\right]_{i}$ changes, while the inactive enzyme had no effect (Figures $2 a-c)$. To study its impact on the dissemination of $\mathrm{Cyt} C$-induced cell death, we loaded the $\mathrm{IP}_{3}$ 5-phosphatase in the trigger zone, together with Cyt $C$. The spread of apoptosis, studied $6 \mathrm{~h}$ later in the communication zone, was significantly reduced in the presence of the active $\mathrm{IP}_{3}$ 5-phosphatase ( $\sim 47 \%$ reduction) (Figure $2 \mathrm{~d}$ ). It is possible that the reduced occurrence of apoptosis in the communication zone results from a less potent stimulation of cell death in the trigger zone. However, the enzyme did not interfere with apoptosis generation induced by a lower concentration of Cyt $C$ $(10 \mu \mathrm{M}$, cell death quantified $25 \mathrm{~min}$ later) in this area (Figure 2e). Thus, the reduced cell death in the communication zone is not the outcome of reduced cell death in this area as such. Loading the $\mathrm{IP}_{3}$ 5-phosphatase in the communication zone instead of the trigger zone caused a significant reduction ( $\sim 54 \%$ ) of caspase-positive cells in the communication zone (Figure 2f). Collectively, these experiments demonstrate that enhancing $\mathrm{IP}_{3}$ degradation in the trigger or communication zone reduces communication of apoptotic cell death.

In a second set of experiments, we investigated the role of the $I P_{3} R$ in the propagation of cell death. Since currently available $I P_{3} R$ inhibitors like xestospongin $B / C$ or 2-aminoethoxydiphenyl borate are membrane-permeable substances, these compounds cannot be specifically targeted to either trigger or communication zone. Therefore, we exploited the $\mathrm{BH} 4$ domain of $\mathrm{Bcl}-2$ (BH4-Bcl-2; $\mathrm{MW} 3.6 \mathrm{kDa})$ to suppress $I_{3} R$ channel opening. Bcl-2 is an anti-apoptotic member of the Bcl-2 family of proteins, which regulate the intrinsic pathway of apoptosis. It differs from the pro-apoptotic members by the presence of a $\mathrm{BH} 4$ domain, which is essential for its anti-apoptotic function. ${ }^{22}$ In addition, the $\mathrm{BH} 4$ domain of Bcl-2 interacts with the $I_{3} R$, thereby suppressing $I P_{3} R$ mediated $\mathrm{Ca}^{2+}$ release and preventing pro-apoptotic $\mathrm{Ca}^{2+}$ signaling. ${ }^{23,24}$ We applied the following synthetic peptides (20 $\mu \mathrm{M}$ final concentration): $\mathrm{BH} 4-\mathrm{Bcl}-2$ peptide (amino acids 6-30 of $\mathrm{Bcl}-2$ ), a mutant $\mathrm{BH} 4-\mathrm{Bcl}-2$ peptide in which the surface-accessible residues have been altered (BIND), a scrambled $\mathrm{BH} 4-\mathrm{Bcl}-2$ (SCR) and an $\mathrm{IP}_{3} \mathrm{R}$-derived peptide (IDP) corresponding to the $\mathrm{Bcl}$-2-binding site on the $\mathrm{IP}_{3} \mathrm{R}$ (amino acids 1389-1408). ${ }^{24}$ The latter acts as a sink for $\mathrm{BH} 4-$ $\mathrm{Bcl}-2$, selectively preventing its action on the $\mathrm{IP}_{3} \mathrm{R}^{23}$ We first checked the outcome of these peptides on caged $\mathrm{IP}_{3}$-induced $\left[\mathrm{Ca}^{2+}\right]_{i}$ elevations (Figure $3 \mathrm{a}$ ). $\mathrm{BH} 4-\mathrm{Bcl}-2$ peptide suppressed the $\mathrm{Ca}^{2+}$ responses and IDP counteracted this effect, demonstrating that $\mathrm{BH} 4-\mathrm{Bcl}-2$ inhibits $\mathrm{IP}_{3} \mathrm{R}$-mediated $\mathrm{Ca}^{2+}$ signaling by directly acting on the $\mathrm{IP}_{3} \mathrm{R}$. Next, we assessed their effect on the communication of apoptosis. Loading of the trigger zone with $\mathrm{BH} 4-\mathrm{Bcl}-2$ (together with $\mathrm{Cyt} C$ ) resulted in a significantly reduced percentage of caspase-positive cells in the communication zone ( $\sim 47 \%$ reduction), whereas the control peptides (BIND, SCR) had no effect (Figure 3b). Most notably, the reduction of apoptosis by $\mathrm{BH} 4-\mathrm{Bcl}-2$ was prevented by inclusion of IDP. The presence of $\mathrm{BH} 4-\mathrm{Bcl}-2$ in the trigger zone did, however, significantly reduce cell death in this zone (tested with $10 \mu \mathrm{M}$ CytC, cell death quantified $25 \mathrm{~min}$ later; Figure $3 \mathrm{c}$ ). In conclusion, the cell death reduction in the communication zone may result from a combination of $I P_{3} R$ inhibition and decreased cell death in the trigger zone with less production of cell death messengers. When $\mathrm{BH} 4-\mathrm{Bcl}-2$ loading was performed in the communication zone, apoptosis was strongly suppressed in this zone ( $\sim 65 \%)$ (Figure $3 d$ ). Thus, $\mathrm{BH} 4-\mathrm{Bcl}-2$ too inhibits the deleterious action of $\mathrm{IP}_{3}$ in the communication zone. 


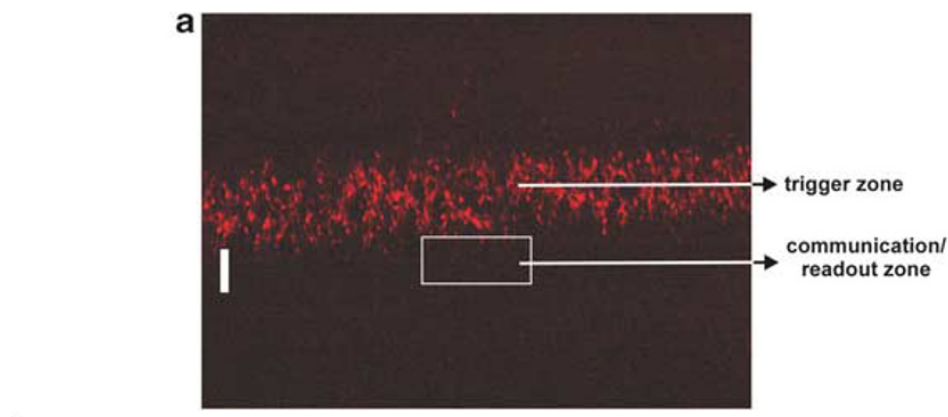

b

C

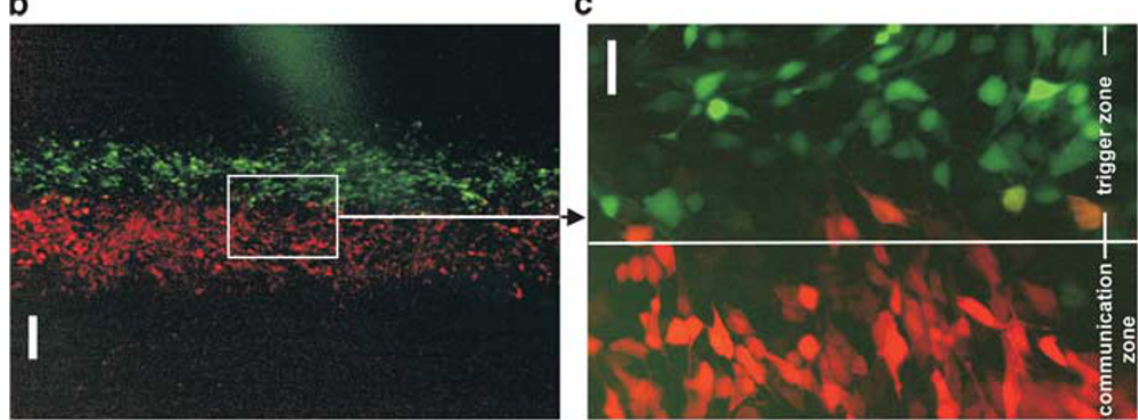

Figure 1 Analysis of propagation of $\mathrm{Cyt} C$-induced apoptotic cell death in a remote non-CytC-loaded zone. (a) A small strip of cells of a $\mathrm{C} 6 \mathrm{C} \times 43 \mathrm{culture}$ loaded with $\mathrm{Cyt} C$ together with DTR ('trigger zone' represented by the red staining) using the in situ electroporation technique. After $6 \mathrm{~h}$, a caspase staining was performed and images were taken with a $\times 10$ objective in a region right next to the trigger zone. ${ }^{11}$ The readout and quantification of bystander death was performed in a zone located $0-200 \mu \mathrm{m}$ away from the trigger zone ('communication zone' indicated by the white rectangle). ( $\mathbf{b}$ and $\mathbf{c})$ Example of a dual electroporation. A C6Cx43 culture was loaded first with the human type I I $P_{3}$ 5-phosphatase or $\mathrm{IP}_{3} \mathrm{R}$ inhibitor BH4-Bcl-2 together with DTR in the communication zone. Subsequently, the trigger zone was loaded with CytC together with FITCdextran. Apoptotic cell death was investigated $6 \mathrm{~h}$ after Cyt $\mathrm{C}$ loading in the communication zone. Note that (i) optimized settings resulted in practically no overlap between the two zones, and (ii) these images were taken immediately after electroporation. The scale bar measures $200 \mu \mathrm{m}$ (a and b) and $50 \mu \mathrm{m}$ (c)

Spread of Cyt $C$-induced cell death in a cell line containing GJs with an impaired permeability to $\mathbf{I P}_{3}$. To obtain more information on whether $\mathrm{IP}_{3}$ diffuses through $\mathrm{GJ}$ during $\mathrm{Cyt} C$-induced cell death, we used a mutant $\mathrm{Cx} 26$ (Cx26V84L), which accounts for non-syndromic hearing loss. ${ }^{25,26}$ Moreover, it forms GJs with a reduced permeability to $\mathrm{IP}_{3}{ }^{26}$ For this purpose, rat C6-glioma cells were lentivirally transduced with cDNA encoding either human wild-type (WT) Cx26 or Cx26V84L. Cells transduced with the empty vector (C6EV) were used as a control. Western blot analysis demonstrated the presence of Cx26 in C6Cx26 and C6Cx26V84L, while no detectable Cx26 immunoreactivity was observed in C6EV (Figure 4a). These results were confirmed by immunostaining, which localized the expression of Cx26 in the cytoplasm as well as in the plasma membrane at regions of contact between adjacent cells (Figure 4b). GJ coupling was studied using the dyes calcein (622 Da, -4) and propidium iodide (PI) (414 Da, +2) (Figure 4c). Dye transfer was comparable between C6Cx26 and C6Cx26V84L, and significantly higher compared to the C6EV. Pre-incubation of C6Cx26 and C6Cx26V84L for $15 \mathrm{~min}$ with the GJ blocker carbenoxolone (Cbx; $50 \mu \mathrm{M})$ strongly limited coupling to levels similar to those observed in C6EV. Next, we analyzed the permeability of channels formed by Cx26V84L to $\mathrm{IP}_{3}$ by monitoring intercellular $\mathrm{Ca}^{2+}$ wave propagation in response to photolytic release of $\mathrm{IP}_{3}$ and in the presence of $10 \mathrm{U} / \mathrm{ml}$ of apyrase $\mathrm{VI}$ and VII. These ATP-degrading enzymes were included to abolish paracrine purinergic communication of $\mathrm{Ca}^{2+}$ wave propagation, leaving GJs as the only pathway for $\mathrm{IP}_{3}$ diffusion. ${ }^{27}$ After photolytically releasing
$\mathrm{IP}_{3}$ in cells located in the center of the field, $\left[\mathrm{Ca}^{2+}\right]_{i}$ rapidly increased, and propagated to neighboring cells (Figure 4d). The extent of the $\mathrm{Ca}^{2+}$ wave was significantly reduced in C6Cx26V84L cells compared with C6Cx26. These results confirm that Cx26V84L GJs exhibit a reduced permeability to $\mathrm{IP}_{3}$, while retaining the ability to transfer different tracers. ${ }^{25,26}$ We then loaded the cell lines with $\mathrm{Cyt} C$ and determined the propagation of apoptosis. In $\mathrm{C} 6 \mathrm{Cx} 26$, this procedure evoked cell death in the trigger zone followed by cell death spread to the communication zone, quantified $6 \mathrm{~h}$ later, as observed in C6Cx43 (Figure 4e). Cbx $(50 \mu \mathrm{M})$, applied $15 \mathrm{~min}$ before Cyt $C$ loading and maintained in the culture medium thereafter $(15 \mathrm{~min}+6 \mathrm{~h})$, reduced apoptosis in the communication zone. Importantly, in C6Cx26V84L cells, apoptosis in the communication zone was reduced to the level observed in C6EV (Figure 4e). Furthermore, loading the $\mathrm{IP}_{3}$ 5-phosphatase in the trigger zone (together with $\mathrm{Cyt} C$ ) significantly reduced apoptosis in the communication zone (Figure 4f). Loading of the $\mathrm{IP}_{3}$ 5-phosphatase in the communication zone also strongly suppressed apoptosis in the same area (Figure $4 \mathrm{~g}$ ).

$\mathrm{IP}_{\mathbf{3}}$ does not evoke cell death by itself. The previous experiments demonstrate that the diffusion of $\mathrm{IP}_{3}$ through GJs is necessary for the communication of apoptosis. Hence, one may anticipate that $\mathrm{IP}_{3}$ is sufficient as a messenger and that elevating $\mathrm{IP}_{3}$ levels in the cells may ensue in cell death. However, loading the trigger zone of $\mathrm{C} 6 \mathrm{Cx} 43$ cells with $50 \mu \mathrm{M} \mathrm{IP}{ }_{3}$ (by in situ electroporation, as for CytC) did not result in apoptosis, neither in the trigger zone $(1.38 \pm 0.3 \%$ for $\mathrm{IP}_{3}+\mathrm{DTR}$ compared to $0.73 \pm 0.1 \%$ for DTR-only; $n=5-6$ ) 


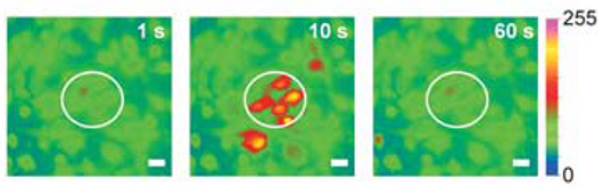

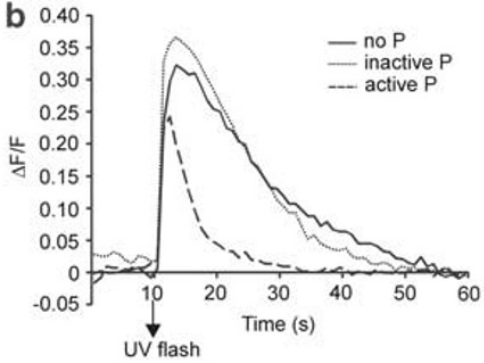
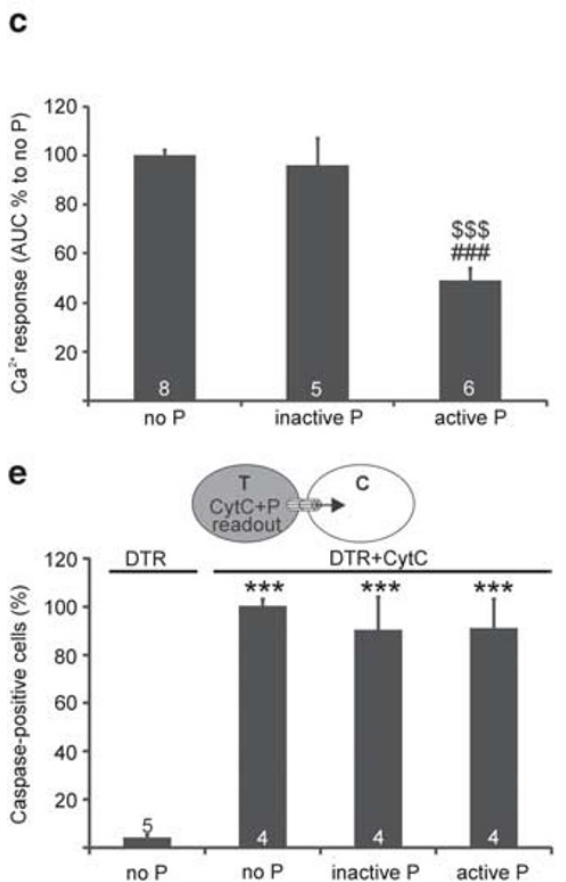

d

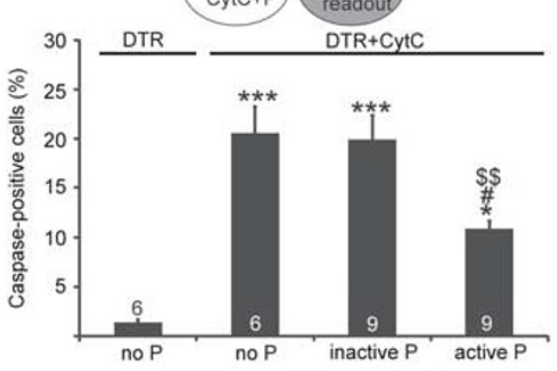

f

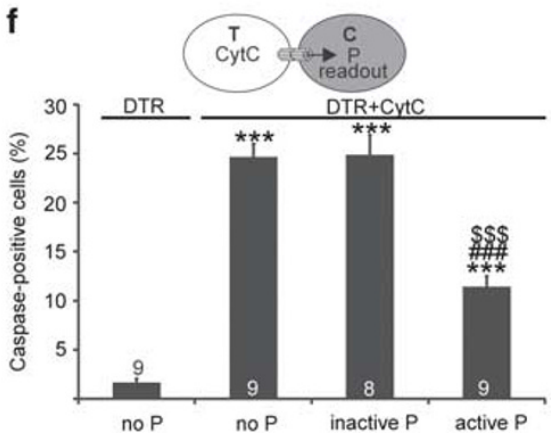

Figure 2 Degrading $\mathrm{IP}_{3}$ by loading the cells with $\mathrm{IP}_{3}$ 5-phosphatase reduces the spread of apoptosis. (a) Representative images showing increases in $\left[\mathrm{Ca}^{2+}\right]_{i}$ after photoliberation of caged $\mathrm{IP}_{3}$ at $9980 \mathrm{~ms}$ of recording. The white circle depicts the area of uncaging and subsequent analysis. The scale bar measures $20 \mu \mathrm{m}$. (b) Traces of individual cells located in the uncaging area containing no $\mathrm{IP}_{3}$ 5-phosphatase (no P), the inactive compound (inactive $\mathrm{P}$ ) or the active $\mathrm{IP}_{3}$ 5-phosphatase $($ active $\mathrm{P}$ ). The $\mathrm{AUC}$ was quantified from these traces for each cell present in the uncaging area and is depicted in the next panel. (c) The active $\mathrm{IP}_{3} 5$-phosphatase significantly reduced caged $\mathrm{IP}_{3}$ induced $\mathrm{Ca}^{2+}$ responses, while the inactive compound had no effect. The conditions with inactive and active $\mathrm{IP}_{3} 5$-phosphatase were normalized to the condition without IP 5-phosphatase. (d) The active $\mathrm{IP}_{3}$ 5-phosphatase significantly decreased apoptosis in the communication zone $6 \mathrm{~h}$ after loading the enzyme together with $\mathrm{Cyt} C$ in the trigger zone. (e) The active $\mathrm{IP}_{3} 5$-phosphatase had no influence on apoptosis induction in the trigger zone, measured 25 min after loading the enzyme together with $C y t C$ in this area. The conditions with inactive and active $\mathrm{IP}_{3}$ 5-phosphatase were normalized to the condition without $I \mathrm{P}_{3} 5$-phosphatase. (f) The active $I \mathrm{P}_{3} 5$-phosphatase significantly reduced the propagation of cell death $6 \mathrm{~h}$ after loading in the communication zone. Illustrations above the bar chart in panels $\mathrm{d}$-f indicate where Cyt $C$ and the $I P_{3} 5$-phosphatase were loaded and where apoptosis was quantified (grey cell-readout). Graphs represent mean \pm S.E.M.; numbers on the bars indicate ' $n$ '; *significance compared to loading with DTR-only; "significance compared to the corresponding bar of the control without $\mathrm{IP}_{3} 5$-phosphatase; and ${ }^{\$}$ significance compared to the corresponding bar of the inactive enzyme. One symbol indicates $P<0.05$, two symbols indicate $P<0.01$ and three symbols indicate $P<0.001\left(P, I P{ }_{3} 5\right.$-phosphatase; $C$, communication zone; T, trigger zone)

nor in the communication zone (Figure 5a). Even very high concentrations, up to $200 \mu \mathrm{M}$, were ineffective. However, combining $\mathrm{IP}_{3}$ loading in the trigger zone with a low concentration of CytC $(10 \mu \mathrm{M})$ potentiated apoptosis in the communication zone, compared to loading with $\mathrm{Cyt} C$ alone (Figure 5a). These results are indicative of a cooperative action of $\mathrm{IP}_{3}$ with other messengers released upon cell death. A plausible co-candidate is $\mathrm{Ca}^{2+}$, which is importantly intertwined in the cascade leading to apoptosis, including the signaling cascade activated by CytC. ${ }^{11,13,16}$ To determine whether $\mathrm{Ca}^{2+}$ acts in cooperation with $\mathrm{IP}_{3}$, we loaded the cells with $50 \mu \mathrm{M} \mathrm{IP}{ }_{3}$ in the presence of a subtoxic concentration $(2 \mu \mathrm{M})$ of the $\mathrm{Ca}^{2+}$ ionophore A23187 (applied immediately after $\mathrm{IP}_{3}$ loading and present the next $6 \mathrm{~h}$ ) to induce $\mathrm{a}\left[\mathrm{Ca}^{2+}\right]_{\mathrm{i}}$ elevation. Similar to $\mathrm{IP}_{3}$ loading without associated $\left[\mathrm{Ca}^{2+}\right]_{\mathrm{i}}$ elevation, no apoptosis was observed $6 \mathrm{~h}$ later in the trigger zone $\left(0.81 \pm 0.2 \%\right.$ for $\mathrm{IP}_{3}+\mathrm{A} 23187$ compared to $1.29 \pm 0.2 \%$ for $\mathrm{IP}_{3}$ and $0.85 \pm 0.1 \%$ for $\left.\mathrm{A} 23187 ; n=4\right)$ and communication zone (Figure 5b). To test whether ER-derived $\mathrm{Ca}^{2+}$, instead of extracellular-derived $\mathrm{Ca}^{2+}$, is more potent, we repeated this experiment with a subtoxic concentration of the SERCA pump inhibitor thapsigargin $(2.5 \mu \mathrm{M})$, a treatment that causes ER emptying by $\mathrm{Ca}^{2+}$ leakage from the store and accelerates staurosporine-induced apoptosis. ${ }^{28}$ With thapsigargin in the culture medium, $\mathrm{IP}_{3}(50 \mu \mathrm{M})$ loading of the trigger zone induced a small but significant increase of caspase-positive cells $6 \mathrm{~h}$ later in this zone $(4.77 \pm 2.7 \%$ for $\mathrm{IP}_{3}+$ thapsigargin compared to $1.29 \pm 0.2 \%$ for $\mathrm{IP}_{3}$ and 
a

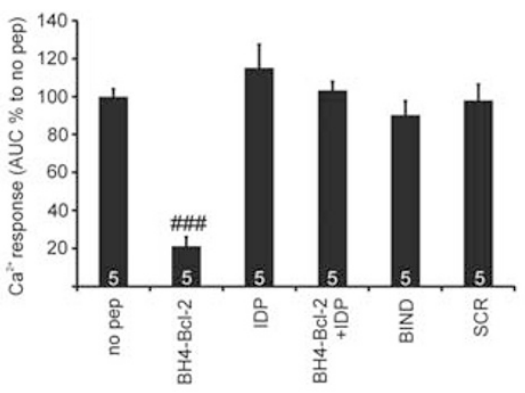

c

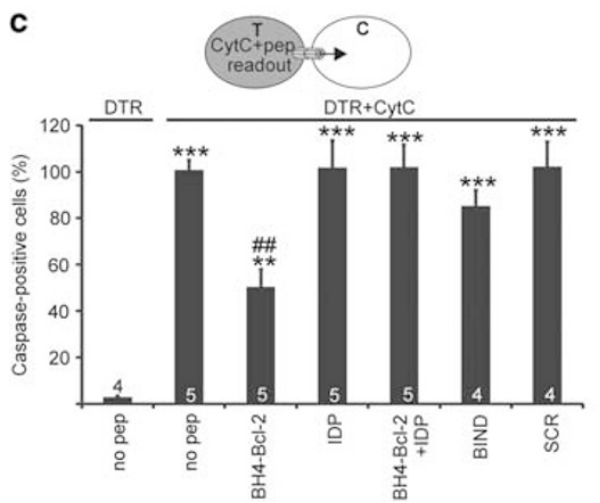

b

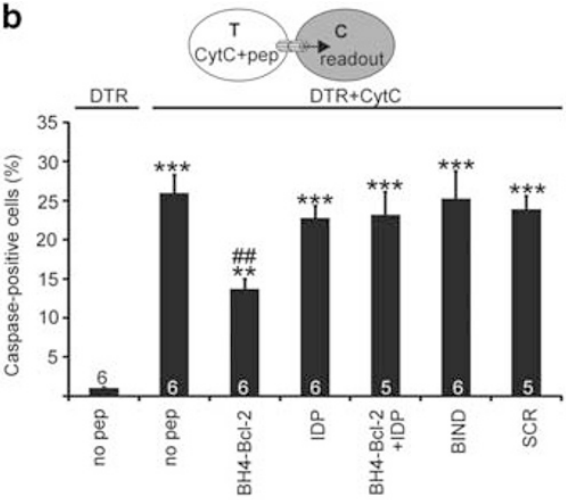

d

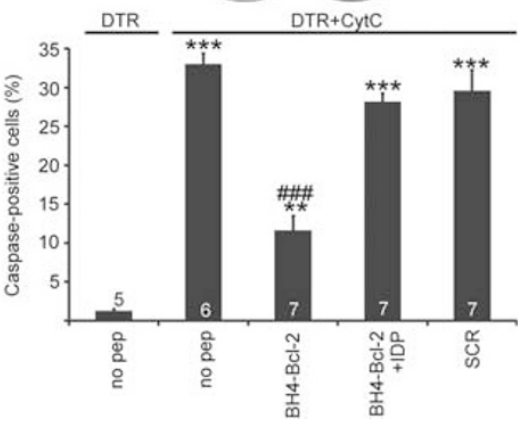

Figure 3 Inhibiting the $\mathrm{IP}_{3} \mathrm{R}$ by loading the cells with the BH4-Bcl-2 peptide reduces the spread of apoptosis. (a) The BH4-Bcl-2 peptide significantly reduced caged $\mathrm{IP}_{3}$-induced $\mathrm{Ca}^{2+}$ responses, while the set of control peptides (SCR and BIND) and a combination of BH4-Bcl-2 and IDP had no effect. The conditions with peptides were normalized to the condition without peptides. (b) $\mathrm{BH} 4-\mathrm{Bcl}-2$ significantly decreased apoptosis in the communication zone $6 \mathrm{~h}$ after loading the peptide together with $\mathrm{Cyt} C \mathrm{C}$ in the trigger zone. The control peptides or BH4-Bcl-2 + IDP had no significant effect. (c) BH4-Bcl-2 significantly reduced apoptosis in the trigger zone 25 min after loading the peptide together with CytC in the trigger zone. The different conditions were normalized to the condition without peptide. (d) BH4-Bcl-2 significantly reduced cell death propagation $6 \mathrm{~h}$ after loading in the communication zone. Illustrations above the bar chart in panels $\mathbf{b}-\mathbf{d}$ indicate where Cyt $C$ and the peptides were loaded and where apoptosis was quantified (grey cell-readout). Graphs represent mean \pm S.E.M.; numbers on the bars indicate ' $n$ '; *significance compared to loading with DTR-only; and \#significance compared to the corresponding bar of the control without peptide. One symbol indicates $P<0.05$, two symbols indicate $P<0.01$ and three symbols indicate $P<0.001$ (pep, peptide; $\mathrm{C}$, communication zone; T, trigger zone)

$1.29 \pm 0.3 \%$ for thapsigargin; $n=4 ; P<0.05)$ and in the communication zone (Figure $5 \mathrm{~b}$ ).

Mitochondrial $\mathrm{Ca}^{2+}$ overload can lead to apoptosis through generation of reactive oxygen species (ROS) ${ }^{29}$ ROS may be transferred via GJs, can modulate $\mathrm{Ca}^{2+}$ dynamics and augment the $\mathrm{Ca}^{2+}$ surge. ${ }^{29,30}$ We examined whether ROS cooperates with $\mathrm{IP}_{3}$ to evoke cell death. Measurement of ROS production with $\mathrm{CM}-\mathrm{H}_{2} \mathrm{DCFDA}$ demonstrated a gradual increase of the fluorescence signal over the $6 \mathrm{~h}$ period after CytC loading (Figure 5c). This increase was blocked by the antioxidant $N$-acetyl L-cysteine (NALC) (1 mM) applied in the medium (added 30 min before Cyt $C$ loading and present $6 \mathrm{~h}$ thereafter). Such treatment did, however, not influence cell death $6 \mathrm{~h}$ later in the communication zone (Figure $5 \mathrm{~d}$ ).

\section{Discussion}

The present work demonstrates that the communication of Cyt $C$-induced apoptosis critically relies on (i) the presence of $\mathrm{IP}_{3}$ in both the apoptosis trigger zone and cell death communication zone, and (ii) the presence of GJs permeable to $\mathrm{IP}_{3}$ (Figure 6 and Table 1 ).
Studies conducted over the past 20 years indicated a crucial role for GJs in the communication of cell death. ${ }^{10}$ One major caveat in this research area still relates to identifying the signals that convey the cell death message. A previous study has already provided important insights, that is, that a minimal gap junctional conductance is necessary to obtain apoptosis in a neighbor coupled cell and that $\mathrm{IP}_{3}$ (based on work with the $I P_{3} R$ inhibitor xestospongin $C$ ) is a strong candidate for passing the death message via GJs. ${ }^{13}$ To unveil the role of $\mathrm{IP}_{3}$ and its receptor in our experimental setting, we applied various tools interfering with $\mathrm{IP}_{3}$-mediated $\mathrm{Ca}^{2+}$ signaling: an $\mathrm{IP}_{3}$ 5-phosphatase, ${ }^{31,32}$ and the $\mathrm{BH} 4$ domain of $\mathrm{Bcl}-2$ as an $\mathrm{IP}_{3} \mathrm{R}$ blocker. ${ }^{23,24}$ In situ electroporation allows loading spatially defined trigger or communication zones with these high-molecular-weight cell-impermeable agents that become trapped in the cells upon introduction. The observed reduction of the spread of cell death after application of $\mathrm{IP}_{3} 5$-phosphatase or $\mathrm{BH} 4-\mathrm{Bcl}-2$ in the trigger or communication zone implies that (i) the generation of $\mathrm{IP}_{3}$ in trigger zone and (ii) the presence of $\mathrm{IP}_{3}$ in the communication are both necessary events for cell death propagation to occur. There is general agreement that a tight interplay between the ER and mitochondria is a control point for apoptosis. ${ }^{4}$ More specifically, 
a strategic positioning of the sites of $\mathrm{IP}_{3} \mathrm{R}$-mediated $\mathrm{Ca}^{2+}$ release in close proximity of the mitochondria results in the formation of an 'ER-to-mitochondria conduit', mitochondrial $\mathrm{Ca}^{2+}$ overload, permeability transition pore (PTP) opening and subsequent release of pro-apoptotic molecules including CytC. ${ }^{3,5}$ A recent report demonstrates that microinjection of $\mathrm{IP}_{3}$ in astrocytes can also evoke Bax translocation to mitochondrial membranes and is accompanied by $\mathrm{Ca}^{2+}$
A

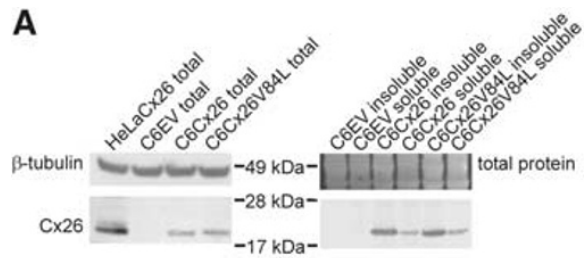

C

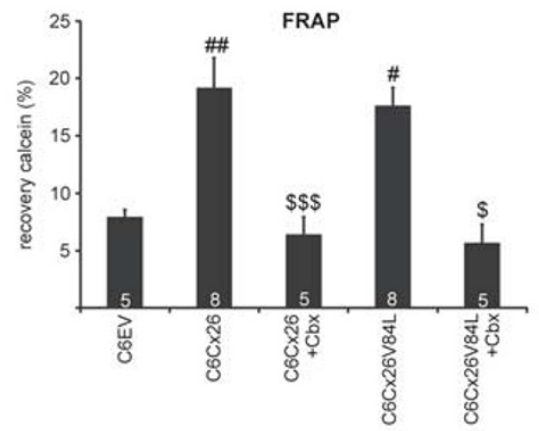

D
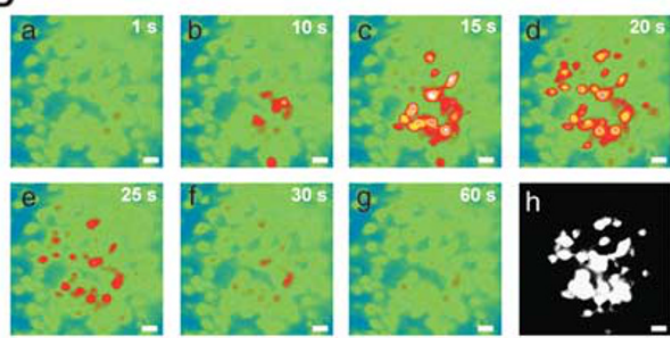

B
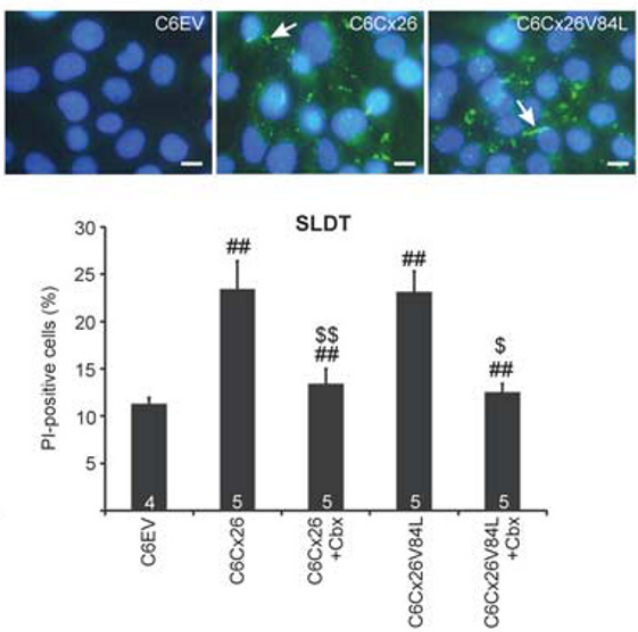
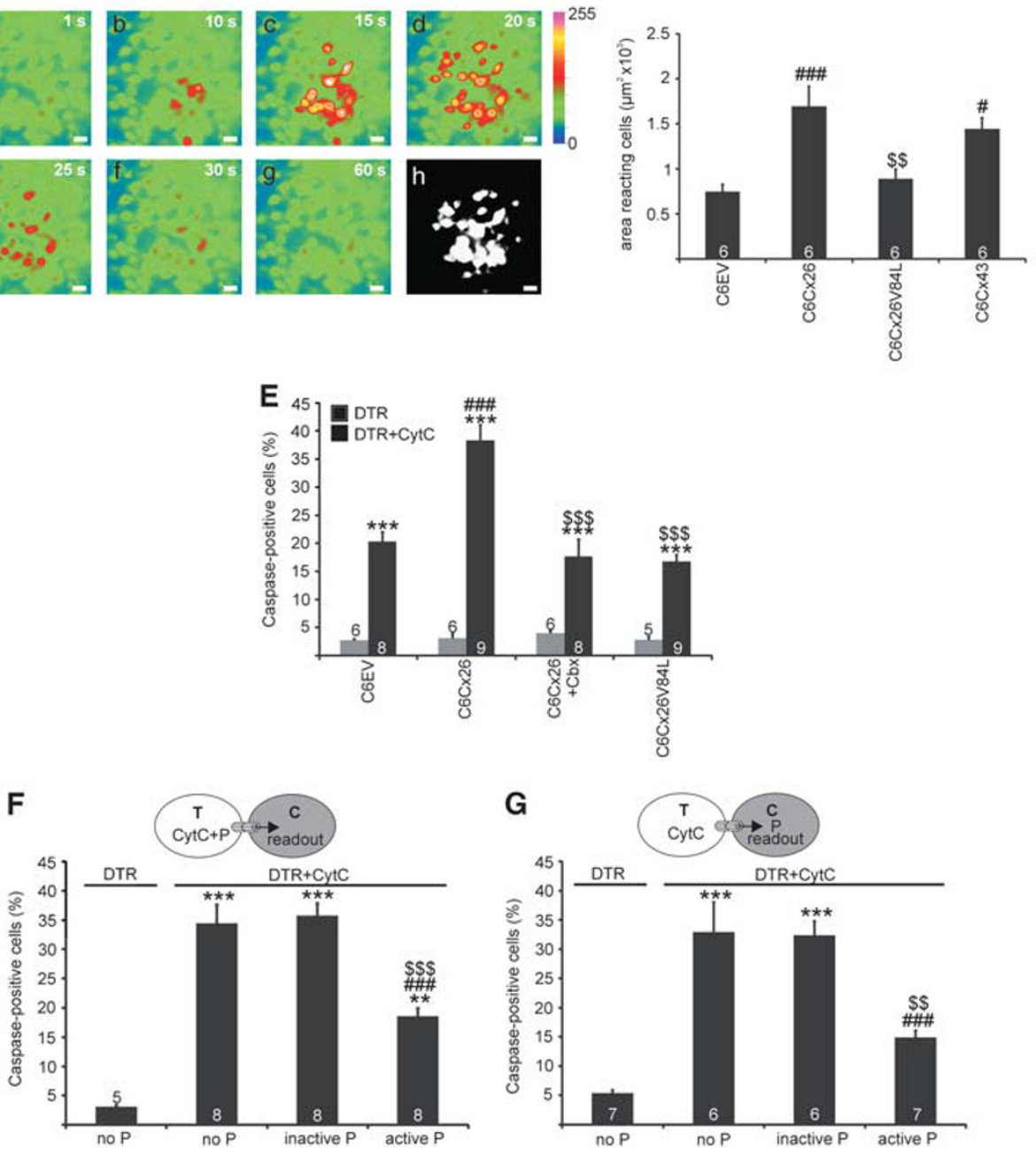
wave propagation to neighboring cells. ${ }^{33}$ In turn, an elevation of $\left[\mathrm{Ca}^{2+}\right]_{\mathrm{i}}$ may provide a positive feedback mechanism for phospholipase $\mathrm{C}$ (PLC) activation to generate $\mathrm{IP}_{3} \cdot{ }^{19}$

Several regulatory mechanisms exist that influence the $\mathrm{IP}_{3} \mathrm{R}$ activity and enable them to modulate $\mathrm{Ca}^{2+}$-dependent apoptotic pathways. ${ }^{3}$ Our finding that $\mathrm{BH} 4-\mathrm{Bcl}-2$, by inhibiting the $I P_{3} R$, significantly reduced CytC-induced apoptosis confirms the previously identified feedforward mechanism. This vicious circle consists of an interaction of $C y t C$ with the
$I P_{3} R$ and alleviation of the inhibitory effect of high $\left[\mathrm{Ca}^{2+}\right]_{i}$ on the $I P_{3} R$, thereby promoting $\mathrm{Ca}^{2+}$ release from the $E R$ and accumulation into the mitochondria with more Cyt $C$ release and caspase activation as a consequence. ${ }^{1,24}$ Thus, the presence of the $\mathrm{IP}_{3} \mathrm{R}$ is a prerequisite for the development of Cyt $C$-induced apoptosis, which seems to be in contrast to the $\mathrm{IP}_{3}$ molecule itself. In our experimental model, the $\mathrm{IP}_{3}$ 5-phosphatase had no discernible effect on cell death in the trigger zone. However, it has to be noted that (i) an incomplete
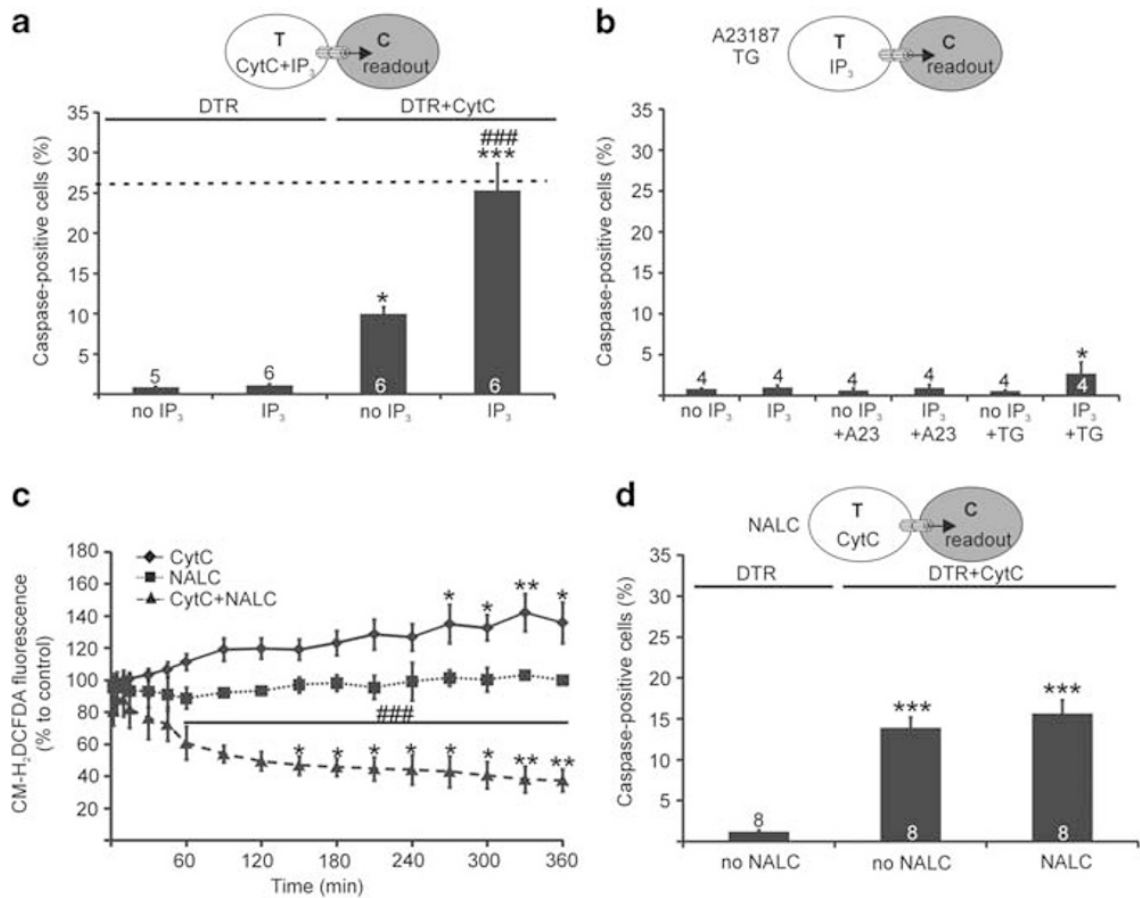

Figure $5 \quad \mathrm{IP}_{3}$ alone or combined with $\mathrm{Ca}^{2+}$ is not sufficient to evoke cell death spread. (a) Loading C6Cx43 cells with $\mathrm{IP}_{3}$ did not result in apoptosis in the communication zone $6 \mathrm{~h}$ after loading. However, combining $\mathrm{IP}_{3}$ with $10 \mu \mathrm{M}$ CytC in the trigger zone potentiated cell death in the communication zone $6 \mathrm{~h}$ later. The percentage of caspasepositive cells in the communication zone was comparable to the $\mathrm{Al}$ after electroporation of $100 \mu \mathrm{M}$ CytC without $\mathrm{IP}_{3}$ (dashed line). (b) $\mathrm{IP}_{3}$ loading combined with $\mathrm{A}_{23187}$ treatment did not evoke cell death dissemination, while the application of thapsigargin (TG) caused a slight increase of apoptosis in the communication zone $6 \mathrm{~h}$ later. (c) CytC loading resulted in a gradual increase in ROS as measured by an augmentation of the fluorescence of CM- ${ }_{2}$ DCFDA. NALC, applied 30 min before and during $6 \mathrm{~h}$ after CytC loading, blocked the production of ROS. The different conditions were normalized to the condition without CytC and NALC $(n=5-9)$. (d) Exposing the cells in the trigger and communication zone to NALC had no influence on spread of apoptosis to the communication zone. Illustrations above the bar chart in panels $\mathbf{a}, \mathbf{b}$ and $\mathbf{d}$ indicate where Cyt $C$, $\mathrm{IP}_{3}, \mathrm{A23187}$, thapsigargin and NALC were applied and where apoptosis was quantified (grey cell-readout). Graphs represent mean \pm S.E.M.; numbers on the bars indicate ' $n$ '; *significance compared to cultures loaded with $\mathrm{IP}_{3}(\mathbf{a}$ and $\mathbf{b})$ ), loading with DTR-only without NALC (c and $\left.\mathbf{d}\right)$; " significance compared to the corresponding bar of the culture loaded with CytC but no $\mathrm{IP}_{3}$ (a) or CytC (c). One symbol indicates $P<0.05$, two symbols indicate $P<0.01$ and three symbols indicate $P<0.001$ (TG, thapsigargin)

Figure 4 GJs with impaired permeability to $\mathrm{IP}_{3}$ reduce the spread of apoptosis. (A) Western blot analysis for Cx26 in the transduced cell lines C6EV, C6Cx26 and C6Cx26V84L. Cx26 expression in total protein lysates and after separation of the Triton X-100 soluble and insoluble fractions; the latter representing the fraction incorporated into GJs. Cx26 expression was comparable between C6Cx26 and C6Cx26V84L, but was absent in C6EV. HeLaCx26 was used as a positive control. $\beta$-Tubulin or total protein staining report equal loading. (B) Overlays of a Cx26 immunostaining (green) and nuclear DAPI staining (blue). The Cx26 expression pattern was similar for Cx26WT and its mutant form, with arrows indicating the presence of gap junctional plaques. The scale bar measures $20 \mu \mathrm{m}$. (C) Gap junctional coupling in the different cell lines as studied with fluorescence recovery after photobleaching (FRAP) and SLDT. Gap junctional coupling was comparable for C6Cx26 and C6Cx26V84L and was inhibited by application of Cbx. (D) Example images showing the dissemination of a $\mathrm{Ca}^{2+}$ wave in $\mathrm{C} 6 \mathrm{Cx} 26$ after photoliberation of caged $\mathrm{IP}_{3}$ at $9980 \mathrm{~ms}$ and in the presence of the ATP-degrading enzyme apyrase $(\mathrm{a}-\mathrm{g})$. Images recorded during $60 \mathrm{~s}$ were corrected for cells reacting immediately to the UV flash, subjected to a threshold and averaged (h). The area of reacting cells was quantified from this image and is depicted in the graph. The V84L mutation significantly reduced caged $\mathrm{IP}_{3}$-induced $\mathrm{Ca}^{2+}$ waves. The scale bar measures $20 \mu \mathrm{m}$. (E) Spread of CytC-induced apoptosis to the communication zone in the different cell lines measured $6 \mathrm{~h}$ after loading. A significantly smaller percentage of caspasepositive cells were detected in the communication zone of $\mathrm{C} 6 \mathrm{EV}$ and $\mathrm{C} 6 \mathrm{C} \times 26 \mathrm{~V} 84 \mathrm{~L}$ compared to $\mathrm{C} 6 \mathrm{Cx} 26$. Cbx reduced the propagation of apoptosis in $\mathrm{C} 6 \mathrm{C} \times 26$ to the level of C6EV. (F) The active $\mathrm{IP}_{3}$ 5-phosphatase significantly decreased apoptosis in the communication zone of $\mathrm{C} 6 \mathrm{Cx} 26$ cultures $6 \mathrm{~h}$ after loading the enzyme together with $\mathrm{Cyt} C$ in the trigger zone. (G) The active $\mathrm{IP}_{3}$ 5-phosphatase also significantly reduced the spread of cell death $6 \mathrm{~h}$ after loading in the communication zone. Illustrations above the bar chart in panels $\mathbf{F}$ and $\mathbf{G}$ indicate where $C y t C$ and the $\mathrm{IP}_{3}$ 5-phosphatase were loaded and where apoptosis was quantified (grey cell-readout). Graphs represent mean \pm S.E.M.; numbers on the bars indicate ' $n$ '; "significance compared to loading with DTR-only (E-G); " significance compared to the corresponding bar of C6EV (C-E) or the corresponding control without phosphatase $(\mathbf{F}$ and $\mathbf{G})$; ${ }^{\$}$ significance compared to $\mathbf{C 6 C x 2 6}(\mathbf{C}-\mathbf{E})$ or the inactive phosphatase $(\mathbf{F}$ and $\mathbf{G})$. One symbol indicates $P<0.05$, two symbols indicate $P<0.01$ and three symbols indicate $P<0.001$ ( $P, \mathrm{IP}_{3}$ 5-phosphatase; $\mathrm{C}$, communication zone; $\mathrm{T}$, trigger zone) 


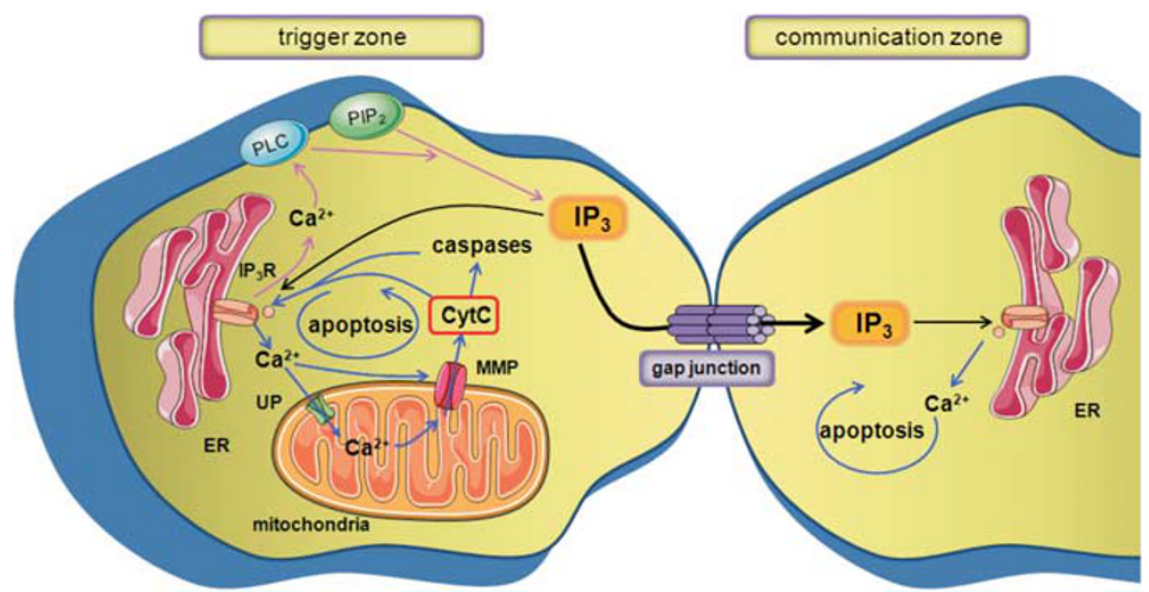

Figure 6 Scheme sketching a hypothetical model for the involvement of $\mathrm{IP}_{3}$ in the propagation of $\mathrm{Cyt} C$-induced apoptosis. After introduction of $\mathrm{Cyt} C$ in the trigger zone, the pro-apoptotic molecule interacts with the $\mathrm{IP}_{3} \mathrm{R}$, resulting in the abolishment of the $\mathrm{Ca}^{2+}$-dependent inhibition of the $\mathrm{IP}_{3} \mathrm{R}$. Consequently, a vicious circle is activated (depicted in blue), consisting of $\mathrm{ER} \mathrm{Ca}^{2+}$ release, mitochondrial $\mathrm{Ca}^{2+}$ accumulation, CytC release and caspase activation. Furthermore, $\mathrm{IP}_{3}$-induced $\mathrm{Ca}^{2+}$ release from the $\mathrm{ER}^{2}$ can provide a positive feedback mechanism for PLC activation and subsequent $I_{3}$ generation (depicted in pink). A small amount of $I P_{3}$ is transferred through $G J s$ and results in apoptosis in the cells in the communication zone. However, additional messengers or conditions seem to be required to convert IP ${ }_{3}$ into a pro-apoptotic molecule. The figure was produced using Servier Medical Art (MMP, mitochondrial membrane permeabilization; UP, uniporter)

Table 1 Summary of the effects of the different substances on apoptosis in the trigger and/or communication zone

\begin{tabular}{lccc}
\hline Compound & Loading zone & Readout zone & Effect on apoptosis \\
\hline CytC & $\mathrm{T}$ & $\mathrm{T}$ & $\mathrm{X}$ \\
$+\mathrm{IP}$ 5-phosphatase & $\mathrm{C}$ & $\mathrm{C}$ & - \\
& $\mathrm{T}$ & $\mathrm{C}$ & - \\
CytC & $\mathrm{T}$ & $\mathrm{C}$ & - \\
$+\mathrm{BH}$-Bcl-2 & $\mathrm{C}$ & $\mathrm{C}$ & - \\
& $\mathrm{T}$ & $\mathrm{T}$ & $\mathrm{X}$ \\
$\mathrm{IP}_{3}$ & $\mathrm{C}$ & $\mathrm{X}$ \\
$+\mathrm{CytC}$ & $\mathrm{T}$ & $\mathrm{C}$ & + \\
$+\mathrm{A} 23187$ & $\mathrm{~T}+\mathrm{C}$ & $\mathrm{T}$ & $\mathrm{X}$ \\
+ thapsigargin & $\mathrm{T}+\mathrm{C}$ & $\mathrm{C}$ & $\mathrm{X}$ \\
$\mathrm{NALC}$ & $\mathrm{T}+\mathrm{C}$ & $\mathrm{C}$ & + \\
\end{tabular}

Abbreviations: $\mathrm{X}$, no effect; -, decrease of apoptotic cells in the readout zone; +, increase in apoptotic cells in the readout zone; T, trigger zone; C, communication zone

degradation of $\mathrm{IP}_{3}$ was observed after flash photolysis of caged $\mathrm{IP}_{3}$, (ii) a small amount of $\mathrm{IP}_{3}$ might be sufficient to spark the vicious cell death cycle and (iii) the $\mathrm{IP}_{3} \mathrm{R}$ can be activated indirectly through the proteolysis by caspase 3 , providing a continuous $\mathrm{Ca}^{2+}$ leak from the ER. ${ }^{20,21}$

Peixoto et al. ${ }^{34}$ recently demonstrated that Bax and/or Bak are required to mediate bystander death induced by transfection of a plasmid encoding GFP-Bax in Bax and Bak doubleknockout mouse embryonic fibroblasts. Many intrinsic apoptotic signals seem to rely on both the release of $\mathrm{Ca}^{2+}$ from the $\mathrm{ER}$ and the presence of Bax and Bak to execute apoptosis. ${ }^{33,35}$ It is important to note that these pro-apoptotic Bcl-2 family members not only act at the level of the mitochondria, but also at the ER. Bax has been demonstrated to promote caspase-independent $\mathrm{Ca}^{2+}$ mobilization from the ER to the mitochondrion through the uniporter during apoptosis, ${ }^{28}$ and to promote $\mathrm{Ca}^{2+}$ wave propagation to neighboring cells. ${ }^{36} \mathrm{On}$ the other hand, reduced ER $\mathrm{Ca}^{2+}$ levels and a decreased mitochondrial $\mathrm{Ca}^{2+}$ uptake were observed in the Bax- and
Bak-deleted mouse embryonic fibroblasts. In this case, increased binding of $\mathrm{Bcl}-2$ to $\mathrm{IP}_{3} \mathrm{R} 1$ caused $\mathrm{IP}_{3} \mathrm{R}$ sensitization, resulting in a basal $I P_{3} \mathrm{R}$-mediated $\mathrm{Ca}^{2+}$ leak, thereby decreasing the sensitivity to apoptotic $\mathrm{Ca}^{2+}$ signaling. ${ }^{35,37}$ Of note, in our model, the $\mathrm{BH} 4-\mathrm{Bcl}-2$ peptide also interacts with the $I P_{3} R$ and inhibits $I_{3}$-induced $\mathrm{Ca}^{2+}$ signaling, but does not influence steady-state ER $\mathrm{Ca}^{2+}$ levels as reported recently. ${ }^{24}$ Although distinct actions of pro- versus antiapoptotic $\mathrm{Bcl}-2$ members in controlling $\mathrm{Ca}^{2+}$ dynamics have been demonstrated, they could both regulate bystander death via a direct or indirect modulation of $\mathrm{IP}_{3}$-induced $\mathrm{Ca}^{2+}$ release.

Convincing evidence to substantiate a role for $\mathrm{IP}_{3}$ as the cell death messenger passing through GJs was obtained in the Cx26V84L cells. While the V84L mutation is characterized by a proper intracellular sorting and similar gap junctional conductances as the Cx26WT, ${ }^{26}$ Cx26V84L-based GJs displayed significantly impaired permeation to $\mathrm{IP}_{3}$ as observed in the spread of intercellular $\mathrm{Ca}^{2+}$ waves. ${ }^{26}$ Several lines of evidence point to $\mathrm{IP}_{3}$ as the responsible messenger for 
$\mathrm{Ca}^{2+}$ wave propagation via GJs composed of $\mathrm{Cx} 26, \mathrm{Cx} 43$ or Cx32. ${ }^{8,38}$ Hence, the reduced spread of apoptosis in C6Cx26V84L cells is related to the defective gap junctional diffusion of $\mathrm{IP}_{3}$. Importantly, the dissemination of cell death in the $\mathrm{C} 6 \mathrm{Cx} 26$ experiments was similar to that in $\mathrm{C} 6 \mathrm{C} \times 43$ cells (1.89 \pm 0.14 -fold more for C6Cx26/C6EV and 1.64 $\pm 0.078-$ fold more for C6Cx43/C6WT) and the size of the intercellular $\mathrm{Ca}^{2+}$ waves did not differ either.

Additional experiments indicated that $\mathrm{Ca}^{2+}$ signals produced by $\mathrm{IP}_{3}$ are handled normally, but potentiated apoptosis spread when superimposed with a low concentration of Cyt $C$. Accordingly, Szalai et al. ${ }^{5}$ demonstrated that $\mathrm{IP}_{3} \mathrm{Rs}$ release very small amounts of $\mathrm{Ca}^{2+}$ to evoke transient PTP opening, mitochondrial depolarization and apoptosis in cells primed with a subtoxic apoptotic trigger. However, under physiological conditions, the event of PTP opening was relatively insensitive to $\mathrm{IP}_{3}$-induced $\mathrm{Ca}^{2+}$ signals. ${ }^{5}$ The mitochondria have been proposed to function as 'coincidence detectors' as oxidative stress-induced apoptosis requires a synergism between high mitochondrial $\mathrm{Ca}^{2+}$ and ROS production to open the PTP and activate caspases. ${ }^{39}$ Combining $\mathrm{IP}_{3}$ with exposure to thapsigargin resulted in a small but significant increase in apoptosis spread in our model system, likely by potentiating mitochondrial $\mathrm{Ca}^{2+}$ overload. In addition, the interplay between $\mathrm{Ca}^{2+}$ dynamics and $\mathrm{IP}_{3}$ metabolism may also play a role. Fluctuations in $\left[\mathrm{Ca}^{2+}\right]_{i}$ do not only influence $\mathrm{IP}_{3}$ production but also its degradation. Binding of $\mathrm{Ca}^{2+} /$ calmodulin to the $\mathrm{IP}_{3}$ 3-kinase enhances its activity, thereby modulating $\mathrm{IP}_{3}$ levels and increasing the concentration of inositol 1,3,4,5-tetrakisphosphate. The latter has a 30 times larger half-life than $\mathrm{IP}_{3}$, may act to sustain $\mathrm{Ca}^{2+}$ signals initiated by $\mathrm{IP}_{3}$ and thus contribute to its pathological function. ${ }^{40}$ Whether the apoptotic signaling pathway in the communication zone proceeds through the above-mentioned vicious circle has to be further investigated. Preliminary experiments with a peptide reported to disrupt the interaction between the $\mathrm{IP}_{3} \mathrm{R}$ and $\mathrm{Cyt} C$, and to inhibit both extrinsic and intrinsic apoptosis, ${ }^{1}$ counteracted caspase activation in the trigger $^{24}$ and communication zone (unpublished observation). These results corroborate the view of a central role for CytC/ $\mathrm{IP}_{3} \mathrm{R}$ signaling in triggering cell death in both areas.

We conclude from this work that the production of $\mathrm{IP}_{3}$ in apoptotic cells, its diffusion through GJs and its actions in recipient cells are important for spreading apoptosis to neighboring cells. $\mathrm{IP}_{3}$ is the key necessary messenger in this process, but other factors seem to be necessary to create conditions in which $\mathrm{IP}_{3}$ will exert pro-apoptotic effects.

\section{Materials and Methods}

Agents. A23187, (caged) IP $\mathrm{P}_{3}$, calcein-AM, CM- $\mathrm{H}_{2} \mathrm{DCFDA}, 10 \mathrm{kDa}$ DTR, Fluo-3$\mathrm{AM}$, Hoechst 33342, PI and pluronic F-127 were purchased from Invitrogen (Merelbeke, Belgium). Apyrase (potato) grade $\mathrm{VI}$ and $\mathrm{VII} ; \mathrm{Cbx}, \mathrm{Cyt} C$ from equine heart, 2',6'-diamidino-2-phenylindole (DAPI), $10 \mathrm{kDa}$ FITC-dextran, NALC, paraformaldehyde (PFA) and probenecid were obtained from Sigma (Bornem, Belgium). The synthetic BH4-domain peptides and IDP were derived from Thermo Electron (Karlsruhe, Germany). ${ }^{24}$ Purification and determination of the activity of the human type I IP 5 -phosphatase $(6 \mu \mathrm{mol} / \mathrm{min}$ per $\mathrm{ml})$ were performed as described previously. ${ }^{32}$ The enzyme was used at a final dilution of $1 / 5000$, which is based on previous experimental work with this compound ${ }^{31}$ taking into account an electroporation loading efficiency of $\sim 27 \% .{ }^{11}$ The $\mathbb{I P}_{3}$ 5-phosphatase was inactivated at $100^{\circ} \mathrm{C}$ for $1 \mathrm{~h}$.
Plasmid construction. The coding region of human Cx26WT and Cx26V84L were amplified by PCR from plasmids Cx26 pIRES-EGFP and Cx26V84L pIRESEGFP, ${ }^{26}$ using the following primers: forward, $5^{\prime}$-ATCCGGTACCGAATTCACCAT GGATTGGGGCACGCTG- $3^{\prime}$ and reverse, $5^{\prime}$-GTCTAGATATCTCGAGTTAAACTG GCTTTTTTGACTTC- $3^{\prime}$. The PCR products were cloned in PENTR3C vectors (Invitrogen) using In-Fusion cloning reaction (Takara Bio Europe/Clontech, Saint-Germain-en-Laye, France) according to the manufacturer's instructions. Subsequently, genes encoding Cx26WT and Cx26V84L were moved to bicistronic vectors to generate pdWPI-IRES-dsRed-Cx26WT and pdWPI-IRES-dsRedCx26V84L, respectively, through an LR recombination reaction (Clonasae Enzyme Mix; Invitrogen) according to the manufacturer's instructions. All constructs were sequenced at the VIB sequencing facility (ABI3730XL; Applied Biosystems, Carlsbad, CA, USA).

Cell culture. Rat C6-glioma cells were cultured in Dulbecco's modified Eagle's medium (DMEM) and Ham's F12 (1:1), containing 10\% fetal bovine serum, $100 \mathrm{U} / \mathrm{ml}$ penicillin, $100 \mu \mathrm{g} / \mathrm{ml}$ streptomycin, $2.5 \mu \mathrm{g} / \mathrm{ml}$ fungizone and $2 \mathrm{mM}$ glutamine (Gibco, Merelbeke, Belgium) at $37^{\circ} \mathrm{C}, 5 \% \mathrm{CO}_{2}$.

Generation of lentivirus and transduction. HEK293T cells were grown in DMEM supplemented with $10 \%$ fetal calf serum (Gibco). HEK293T cells were seeded in $25 \mathrm{~cm}^{2}$ flasks at $1.5 \times 10^{5}$ cells per $\mathrm{ml}$ and transfected the following day using the $\mathrm{Ca}^{2+}$ phosphate method with $4 \mu \mathrm{g}$ of pdWPI-IRES-dsRed-Cx26WT or pdWPI-IRES-dsRed-Cx26V84L. Each transfection also included $1.2 \mu \mathrm{g}$ of a plasmid encoding VSV-G (pMD2-VSV-G; Tronolab, Lausanne, France) and $2.6 \mu \mathrm{g}$ of a plasmid encoding packaging proteins (pCMVdR8.9; Tronolab). VSV-Gpseudotyped virus was collected $24 \mathrm{~h}$ after transfection, passed through $0.45 \mu \mathrm{m}$ filters and then added to the exponentially growing $\mathrm{C} 6$ cell cultures in the presence of $8 \mu \mathrm{g} / \mathrm{ml}$ of polybrene. Two sequential infections were carried out, each one for $24 \mathrm{~h}$. The cells were expanded and then sorted on the EPICS ALTRA flow cytometer (Beckman Coulter, Analis SA, Suarlée, Belgium) for red-positive cells.

Electroporation loading. Cells were grown to near confluency on 4-well plates, 13 or $18 \mathrm{~mm}$ diameter glass coverslips depending on the ensuing experiment (oxidative stress measurements, apoptosis detection or caged $\mathrm{IP}_{3}$ photoliberation). Cell monolayer cultures were washed three times with Hanks' balanced salt solution buffered with Hepes (HBSS-Hepes) supplemented with glucose $(0.81 \mathrm{mM}$ $\mathrm{MgSO}_{4} \cdot 7 \mathrm{H}_{2} \mathrm{O}, 0.95 \mathrm{mM} \mathrm{CaCl}_{2} \cdot 2 \mathrm{H}_{2} \mathrm{O}, 137 \mathrm{mM} \mathrm{NaCl}, 0.18 \mathrm{mM} \mathrm{Na}_{2} \mathrm{HPO}_{4} \cdot 2 \mathrm{H}_{2} \mathrm{O}$, $5.36 \mathrm{mM} \mathrm{KCl}, 0.44 \mathrm{mM} \mathrm{KH}_{2} \mathrm{PO}_{4}, 5.55 \mathrm{mM}$ D-glucose, $25 \mathrm{mM}$ Hepes, pH 7.4) and subsequently three times with a low conductivity electroporation buffer $(4.02 \mathrm{mM}$ $\mathrm{KH}_{2} \mathrm{PO}_{4}, 10.8 \mathrm{mM} \mathrm{K}_{2} \mathrm{HPO}_{4}, 1.0 \mathrm{mM} \mathrm{MgCl}, 300 \mathrm{mM}$ sorbitol, $2.0 \mathrm{mM}$ Hepes, $\mathrm{pH}$ 7.4). They were placed $400 \mu \mathrm{m}$ underneath a two-wire Pt-Ir electrode on the microscopic stage and electroporated in the presence of a tiny amount of electroporation solution $(10 \mu \mathrm{l})$ containing $100 \mu \mathrm{M}$ CytC and $100 \mu \mathrm{M} 10 \mathrm{kDa}$ DTR. Control cultures were electroporated with solution containing only $100 \mu \mathrm{M}$ DTR. In some cases, where a restricted amount of apoptosis was required, lower CytC concentrations $(10 \mu \mathrm{M})$ were applied (see Results section). Electroporation was carried out with $50 \mathrm{kHz}$ bipolar pulses applied as trains of 10 pulses of $2 \mathrm{~ms}$ duration each and repeated 15 times. The field strength was $100 \mathrm{~V}$ peak-to-peak applied over a $500 \mu \mathrm{m}$ electrode separation distance. After electroporation, cells were thoroughly washed with HBSS-Hepes.

In the dual electroporation protocol, two areas were subsequently loaded with different substances (Figures $1 \mathrm{~b}$ and c). A first zone ('communication zone') was electroporated with substances interfering with the $\mathrm{IP}_{3}$ signaling machinery (see Results section) together with $100 \mu \mathrm{M}$ DTR. Subsequently, the culture was washed three times with HBSS-Hepes and three times with electroporation buffer after which it was placed again on the microscopic stage. The DTR electroporated zone was located using epifluorescence settings and positioned horizontally. The upper wire of the electrode was placed right underneath the red-stained area, $400 \mu \mathrm{m}$ above the cells. A second zone ('trigger zone') was loaded with $100 \mu \mathrm{M}$ Cyt $C$ and $100 \mu \mathrm{M}$ FITC-dextran. These settings resulted in practically no overlap between the two zones. Visual inspection of the fluorescent areas right after electroporation allowed one to evaluate the precise position of the two electroporated regions.

Apoptosis detection. After electroporation, cells were kept in $200 \mu$ l culture medium until scored for the apoptotic index (Al). This procedure consisted of detecting caspase-positive cells by staining with $10 \mu \mathrm{M}$ of the CaspACE FITC-VADFMK In situ Marker from Promega (Promega Benelux, Leiden, The Netherlands) in HBSS-Hepes for $40 \mathrm{~min}$ at $37^{\circ} \mathrm{C}$. After fixing the cells with $4 \%$ PFA for $25 \mathrm{~min}$ at 
room temperature, nuclei were additionally stained for $5 \mathrm{~min}$ with $1 \mu \mathrm{g} / \mathrm{ml} \mathrm{DAPI} \mathrm{in}$ PBS supplemented with $\mathrm{Ca}^{2+}$ and $\mathrm{Mg}^{2+}(\mathrm{PBSD}+)$. Cells were mounted with Vectashield fluorescent mounting medium (VWR International, Leuven, Belgium) on glass slides. After staining, five images (in each culture) were taken in the zone adjacent to the CytC loaded zone containing the 'communication zone' (Figure 1a) using a Nikon TE300 epifluorescence microscope equipped with a $\times 10$ objective (Plan APO, NA 0.45; Nikon) and a Nikon DS-Ri1 camera (Nikon Belux, Zaventem, Belgium). The number of caspase-positive cells were counted in each image and expressed relative to the number of nuclei present and stated as the Al. Small groups of apoptotic bodies were counted as remnants of a single apoptotic cell. Analyses were carried out blinded and making use of custom-developed counting software.

Caged IP ${ }_{3}$ loading and photolytic release. Cells were seeded on $18 \mathrm{~mm}$ diameter glass coverslips and ester-loaded for $25 \mathrm{~min}$ with $5 \mu \mathrm{M}$ Fluo-3-AM in HBSS-Hepes supplemented with $1 \mathrm{mM}$ of probenecid and $0.01 \%$ pluronic $\mathrm{F}-127$ at $37^{\circ} \mathrm{C}$, followed by a de-esterification over $15 \mathrm{~min}$. Subsequently, cells were loaded with $50 \mu \mathrm{M}$ caged $\mathrm{IP}_{3}$ and $100 \mu \mathrm{M}$ DTR using the in situ electroporation technique as described above. Imaging was carried out using an inverted fluorescence microscope equipped with an $\times 40$ oil-immersion objective (S Fluor, NA 1.30; Nikon) and an intensified CCD camera (Extended Isis camera, Photonic Science, East Sussex, UK). A total of 60 images were generated at 1 image per $s$ with the software written in Microsoft Visual $\mathrm{C}^{++}$6.0. After $10 \mathrm{~s}, \mathrm{IP}_{3}$ photolysis was induced by $20 \mathrm{~ms}$ spot illumination with a $1 \mathrm{kHz}$ pulsed UV laser source $(349 \mathrm{~nm}$ UV laser Explorer; Spectra-Physics, Newport, Irvine, CA, USA) (1800 $\mu$ J energy measured at the entrance of the microscope epifluorescence tube). Fluorescence intensity changes in cells in a region delineated by the UV laser beam width at $15 \%$ of its maximum energy were analyzed with custom-developed FluoFrames software ( $\mathrm{L}$ Leybaert, Ghent, Belgium) (Figure 2a). $\mathrm{Ca}^{2+}$ changes were quantified as the area under the curve (AUC) of the separate $\mathrm{Ca}^{2+}$ traces (Figure $2 b$ ). A UV flash was applied at five different zones along the electroporated area per dish. For the $\mathrm{Ca}^{2+}$ wave experiments, cultures were loaded with $100 \mu \mathrm{M}$ caged $\mathrm{IP}_{3}$ and a UV flash was applied at at least 10 different places along the electroporated area per dish in the presence of $5 \mathrm{U} / \mathrm{ml}$ apyrase VI and VII. Images were calculated for relative fluorescence changes and an image taken right after the UV flash was subtracted to eliminate cells responding directly to the flash. The propagation of intercellular $\mathrm{Ca}^{2+}$ waves was expressed as the area of cells displaying fluorescence changes at least $5 \%$ above of the resting value.

Immunocytochemistry. Cells on coverslips were fixed for 25 min with $4 \%$ PFA and permeabilized for $10 \mathrm{~min}$ with $0.2 \%$ Triton $X-100$. Cells were immunolabeled overnight with polyclonal rabbit anti-Cx26 antibody (1/50 dilution in PBSD + with $0.4 \%$ gelatin; Invitrogen) and subsequently incubated for another hour with secondary Alexa 488-conjugated goat anti-mouse IgG (1/500 dilution; Invitrogen). The nuclei were stained with $1 \mu \mathrm{g} / \mathrm{ml} \mathrm{DAPI}$ in PBSD + for $10 \mathrm{~min}$ and cells were mounted with Vectashield fluorescent mounting medium onto glass slides. All steps were carried out at room temperature and cell cultures were rinsed thoroughly with PBSD + between all incubation steps. Samples were examined and photographed with the microscope as described for apoptosis detection using a $\times 40$ oil-immersion objective.

Western blotting. Cells were seeded in $75 \mathrm{~cm}^{2}$ falcons. Total cell protein lysates were extracted in ice-cold radio-immuno precipitation assay buffer and sonicated five times for $10 \mathrm{~s}$. For separation of Triton X-100 soluble and insoluble fractions, cells were harvested in ice-cold 1\% Triton X-100 in PBS supplemented with $50 \mathrm{mM} \mathrm{NaF}, 1 \mathrm{mM} \mathrm{Na}_{3} \mathrm{VO}_{4}, 1 \%$ protease inhibitor cocktail (Sigma), $1 \%$ phosphatase inhibitor cocktail 1 and 2 (Sigma) and mini-EDTA-free protease cocktail (Roche Diagnostics, Penzberg, Germany). Samples were separated into a soluble and insoluble fraction by centrifugation at $16000 \times g$ for $10 \mathrm{~min}$. Insoluble pellets were resuspended in Laemmli sample buffer and sonicated five times for $10 \mathrm{~s}$. Protein concentrations were determined using a Bio-Rad DC protein assay kit (Bio-Rad, Nazareth, Belgium). Thereafter, $50 \mu \mathrm{g}$ of protein lysates were separated on a $4-12 \%$ Bis-Tris gel (Invitrogen) and subsequently transferred onto a nitrocellulose membrane (Amersham Pharmacia Biotech, Buckinghamshire, UK). Membranes were blocked with $5 \%$ non-fat milk in Tris-buffered saline containing $0.1 \%$ Tween-20 and probed with the polyclonal rabbit anti-Cx26 antibody (1/2000 dilution; Invitrogen), followed by secondary alkaline phosphatase-conjugated goat anti-rabbit IgG antibody (1/8000 dilution; Sigma). Detection was carried out using the BCIP/NBT kit (Zymed, Invitrogen) according to the manufacturer's instructions. As a loading control, the membranes were immunoblotted for rabbit anti- $\beta$-tubulin antibody (1/1000; Abcam, Cambridge, UK), followed by a secondary horse radish peroxidase-conjugated anti-rabbit IgG antibody (1/1000 dilution; Cell signaling, Leiden, The Netherlands) and detected with Lumiglo chemiluminescent substrate (Cell signaling). Total protein staining was carried out with SYPRO Ruby protein blot dye (Invitrogen, Molecular Probes, Merelbeke, Belgium).

Fluorescence recovery after photobleaching. Cells were seeded on $9.2 \mathrm{~cm}^{2}$ Petri dishes (TPP, Trasadingen, Switzerland) and experiments were carried out at near confluency. Cells were loaded for $40 \mathrm{~min}$ at room temperature with the GJ-permeable fluorescent tracer calcein-AM $(10 \mu \mathrm{M})$ in HBSS-Hepes, followed by a de-esterification over $15 \mathrm{~min}$. After extensive rinsing, cultures were transferred to the stage of a custom-made video-rate confocal laser scanning microscope. Fluorescence within a single cell was photobleached by a $1 \mathrm{~s}$ spot exposure to $488 \mathrm{~nm}$ Argon laser light and dye influx from neighboring cells was recorded over the next 5 min with a $\times 40$ water-immersion objective (Fluor, NA 0.8W; Nikon). At the end of the $5 \mathrm{~min}$ period, fluorescence in the bleached cell was expressed as the percentage of recovery relative to the starting level just before photobleaching, a measure of the degree of GJ dye coupling. Cbx was included during the de-esterification period and was also present during the measurements.

Scrape loading and dye transfer. Cells were seeded in 4-well plates and grown to near confluency. They were then washed two times with nominally $\mathrm{Ca}^{2+}$. free scrape loading and dye transfer (SLDT) buffer $(137 \mathrm{mM} \mathrm{NaCl}, 5.36 \mathrm{mM} \mathrm{KCl}$, $0.81 \mathrm{mM} \mathrm{MgCl}{ }_{2} \cdot 6 \mathrm{H}_{2} \mathrm{O}, 5.55 \mathrm{mM}$ D-glucose, $25 \mathrm{mM}$ Hepes, $\mathrm{pH}$ 7.4), incubated for $1 \mathrm{~min}$ in SLDT buffer supplemented with the GJ-permeable tracer PI $(1 \mathrm{mM})$ and a linear scratch was applied to the monolayer with a syringe needle. After $5 \mathrm{~min}$, the dye was washed away with HBSS-Hepes and the cells were left for 15 min in HBSSHepes supplemented with $2 \mu \mathrm{g} / \mathrm{ml}$ Hoechst 33342 to allow the reporter dye to spread between cells via GJs and to stain the nuclei (all performed at room temperature). Images, 8 per well right next to the scrape, were acquired with $a \times 10$ objective and the microscope as described for apoptosis detection. Gap junctional communication was quantified by counting the PI-positive nuclei and expressing them relative to the number of Hoechst-stained nuclei. Cbx was also present during the $15 \mathrm{~min}$ period after the linear scratch was made.

Oxidative stress measurements. Cells were loaded for 30 min with $10 \mu \mathrm{M}$ $\mathrm{CM}-\mathrm{H}_{2} \mathrm{DCFDA}$ in HBSS-Hepes at room temperature, followed by a de-esterification period of $15 \mathrm{~min}$. Subsequently cells were electroporated with $100 \mu \mathrm{M}$ CytC and $100 \mu \mathrm{M}$ DTR and kept in $200 \mu \mathrm{l}$ culture medium. At defined time points, CM- $\mathrm{H}_{2}$ DCFDA fluorescence was measured with a plate reader (Victor-3, type 1420; Perkin-Elmer, Brussels, Belgium). Fluorescence values were corrected for background measurements (non-loaded cells) and normalized to control values (loaded with DTR-only).

Data and statistical analysis. Data are expressed as mean \pm S.E.M., with ' $n$ ' denoting the number of independent experiments. Multiple groups were compared by one-way ANOVA and a Bonferroni post hoc test using the GraphPad Instat software (Graphpad Software, San Diego, CA, USA). Statistical significance is indicated in the graphs by one symbol for $P<0.05$, two symbols for $P<0.01$ and three symbols for $P<0.001$.

\section{Conflict of Interest}

The authors declare no conflict of interest.

Acknowledgements. This work was impossible without the technical assistance of Ms Kirsten Leurs, Ms Anneleen Decock, Ms Marlies Bekaert, Ms Liesbeth Heyndrickx and Mr Eric Tack. We also gratefully acknowledge Mr Timothy Voorspoels for developing analysis tools and software. We thank Dr. D Boehning (Department of Neuroscience and Cell Biology, University of Texas Medical Branch, Galveston, TX, USA) for providing the IP3RCYT peptide. Our work is supported by: the Fund for Scientific Research Flanders (FWO-Vlaanderen), Belgium (G.0140.08, G.0134.09, G.0298.11N and WO.005.10N) and the Interuniversity Attraction Poles Program (Belgian Science Policy, project P6/31) assigned to LL; FWO (G.072810) assigned to DVK; a Methusalem grant (BOF09/01M00709) from the Flemish Government assigned to PV; FWO (G.0788.11N), the Research Council of the KU Leuven via OT START-1 (SRT/10/044) and the Interuniversity Attraction Poles Program (P6/28) assigned to GB; and the Interuniversity Attraction Poles Program (P6/28) assigned to CE. 
1. Boehning D, van Rossum DB, Patterson RL, Snyder SH. A peptide inhibitor of cytochrome c/inositol 1,4,5-trisphosphate receptor binding blocks intrinsic and extrinsic cell death pathways. Proc Natl Acad Sci USA 2005; 102: 1466-1471

2. Verkhratsky A. Calcium and cell death. Subcell Biochem 2007; 45: 465-480.

3. Decuypere JP, Monaco G, Bultynck G, Missiaen L, De Smedt H, Parys JB. The IP(3) receptor-mitochondria connection in apoptosis and autophagy. Biochim Biophys Acta 2011; 1813: 1003-1013

4. Sammels E, Parys JB, Missiaen L, De Smedt H, Bultynck G. Intracellular $\mathrm{Ca}^{2+}$ storage in health and disease: a dynamic equilibrium. Cell Calcium 2010; 47: 297-314.

5. Szalai G, Krishnamurthy R, Hajnoczky G. Apoptosis driven by IP(3)-linked mitochondrial calcium signals. EMBO J 1999; 18: 6349-6361.

6. Dupont $\mathrm{G}$, Combettes L, Leybaert L. Calcium dynamics: spatio-temporal organization from the subcellular to the organ level. Int Rev Cytol 2007; 261: 193-245

7. Rong YP, Distelhorst $\mathrm{CW}$. Bcl-2 protein family members: versatile regulators of calcium signaling in cell survival and apoptosis. Annu Rev Physiol 2008; 70: 73-91.

8. Boitano S, Dirksen ER, Sanderson MJ. Intercellular propagation of calcium waves mediated by inositol trisphosphate. Science 1992; 258: 292-295.

9. Saez JC, Berthoud VM, Branes MC, Martinez AD, Beyer EC. Plasma membrane channels formed by connexins: their regulation and functions. Physiol Rev 2003; 83: 1359-1400.

10. Decrock E, Vinken M, De Vuyst E, Krysko DV, D'Herde K, Vanhaecke T et al. Connexinrelated signaling in cell death: to live or let die? Cell Death Differ 2009; 16: 524-536.

11. Decrock E, De Vuyst E, Vinken M, Van Moorhem M, Vranckx K, Wang N et al. Connexin 43 hemichannels contribute to the propagation of apoptotic cell death in a rat $\mathrm{C} 6$ glioma cell model. Cell Death Differ 2009; 16: 151-163.

12. Cusato K, Bosco A, Rozental R, Guimaraes CA, Reese BE, Linden R et al. Gap junctions mediate bystander cell death in developing retina. J Neurosci 2003; 23: 6413-6422.

13. Cusato K, Ripps H, Zakevicius J, Spray DC. Gap junctions remain open during cytochrome c-induced cell death: relationship of conductance to 'bystander' cell killing. Cell Death Differ 2006; 13: 1707-1714.

14. Frank DK, Szymkowiak B, Josifovska-Chopra O, Nakashima T, Kinnally KW. Single-cell microinjection of cytochrome $c$ can result in gap junction-mediated apoptotic cell death of bystander cells in head and neck cancer. Head Neck 2005; 27: 794-800.

15. Udawatte $\mathrm{C}$, Ripps $\mathrm{H}$. The spread of apoptosis through gap-junctional channels in $\mathrm{BHK}$ cells transfected with Cx32. Apoptosis 2005; 10: 1019-1029.

16. Peixoto PM, Ryu SY, Pruzansky DP, Kuriakose M, Gilmore A, Kinnally KW. Mitochondria apoptosis is amplified through gap junctions. Biochem Biophys Res Commun 2009; 390 38-43.

17. Decrock E, Vinken M, Bol M, D'Herde K, Rogiers V, Vandenabeele P et al. Calcium and connexin-based intercellular communication, a deadly catch? Cell Calcium 2011; 50: 310-321.

18. Allbritton NL, Meyer $T$, Stryer $L$. Range of messenger action of calcium ion and inosito 1,4,5-trisphosphate. Science 1992; 258: 1812-1815

19. Hofer T, Venance L, Giaume C. Control and plasticity of intercellular calcium waves in astrocytes: a modeling approach. J Neurosci 2002; 22: 4850-4859.

20. Assefa Z, Bultynck G, Szlufcik K, Nadif Kasri N, Vermassen E, Goris J et al. Caspase-3induced truncation of type 1 inositol trisphosphate receptor accelerates apoptotic cell death and induces inositol trisphosphate-independent calcium release during apoptosis. J Bio Chem 2004; 279: 43227-43236.

21. Verbert L, Lee B, Kocks SL, Assefa Z, Parys JB, Missiaen L et al. Caspase-3-truncated type 1 inositol 1,4,5-trisphosphate receptor enhances intracellular $\mathrm{Ca}^{2+}$ leak and disturbs $\mathrm{Ca}^{2+}$ signalling. Biol Cell 2008; 100: 39-49.

22. Huang DC, Adams JM, Cory S. The conserved N-terminal BH4 domain of Bcl-2 homologues is essential for inhibition of apoptosis and interaction with CED-4. EMBO 1998; 17: 1029-1039.
23. Rong YP, Bultynck G, Aromolaran AS, Zhong F, Parys JB, De Smedt $\mathrm{H}$ et al. The BH4 domain of $\mathrm{Bcl}-2$ inhibits $\mathrm{ER}$ calcium release and apoptosis by binding the regulatory and coupling domain of the IP3 receptor. Proc Natl Acad Sci USA 2009; 106: 14397-14402.

24. Monaco G, Decrock E, Akl H, Ponsaerts R, Vervliet T, Luyten T et al. Selective regulation of $\mathrm{IP}(3)$-receptor-mediated $\mathrm{Ca}(2+)$ signaling and apoptosis by the $\mathrm{BH} 4$ domain of $\mathrm{Bcl}-2$ versus Bcl-XI. Cell Death Differ 2011; e-pub ahead of print 5 August 2011.

25. Bruzzone R, Veronesi V, Gomes D, Bicego M, Duval N, Marlin S et al. Loss-of-function and residual channel activity of connexin26 mutations associated with non-syndromic deafness. FEBS Lett 2003; 533: 79-88.

26. Beltramello M, Piazza V, Bukauskas FF, Pozzan T, Mammano F. Impaired permeability to Ins $(1,4,5) P 3$ in a mutant connexin underlies recessive hereditary deafness. Nat Cell Bio 2005; 7: 63-69.

27. Anselmi F, Hernandez VH, Crispino G, Seydel A, Ortolano S, Roper SD et al. ATP release through connexin hemichannels and gap junction transfer of second messengers propagate $\mathrm{Ca}^{2+}$ signals across the inner ear. Proc Natl Acad Sci USA 2008; 105 : 18770-18775.

28. Nutt LK, Chandra J, Pataer A, Fang B, Roth JA, Swisher SG et al. Bax-mediated $\mathrm{Ca}^{2+}$ mobilization promotes cytochrome $c$ release during apoptosis. J Biol Chem 2002; 277: 20301-20308.

29. Peng TI, Jou MJ. Oxidative stress caused by mitochondrial calcium overload. Ann $N Y$ Acad Sci 2010; 1201: 183-188.

30. Tang EH, Vanhoutte PM. Gap junction inhibitors reduce endothelium-dependent contractions in the aorta of spontaneously hypertensive rats. J Pharmacol Exp Ther 2008; 327: 148-153.

31. Dupont G, Koukoui O, Clair C, Erneux C, Swillens S, Combettes L. Ca ${ }^{2+}$ oscillations in hepatocytes do not require the modulation of InsP3 3-kinase activity by $\mathrm{Ca}^{2+}$. FEBS Lett 2003; 534: 101-105.

32. De Smedt $F$, Verjans B, Mailleux $P$, Erneux $C$. Cloning and expression of human brain type I inositol 1,4,5-trisphosphate 5-phosphatase. High levels of mRNA in cerebellar Purkinje cells. FEBS Lett 1994; 347: 69-72.

33. Morales AP, Carvalho AC, Monteforte PT, Hirata H, Han SW, Hsu YT et al. Endoplasmic reticulum calcium release engages Bax translocation in cortical astrocytes. Neurochem Res 2011; 36: 829-838.

34. Peixoto PM, Lue JK, Ryu SY, Wroble BN, Sible JC, Kinnally KW. Mitochondrial apoptosisinduced channel (MAC) function triggers a Bax/Bak-dependent bystander effect. Am J Pathol 2011; 178: 48-54.

35. Scorrano L, Oakes SA, Opferman JT, Cheng EH, Sorcinelli MD, Pozzan T et al. BAX and BAK regulation of endoplasmic reticulum $\mathrm{Ca}^{2+}$ : a control point for apoptosis. Science (New York, NY) 2003; 300: 135-139.

36. Carvalho AC, Sharpe J, Rosenstock TR, Teles AF, Youle RJ, Smaili SS. Bax affects intracellular $\mathrm{Ca}^{2+}$ stores and induces $\mathrm{Ca}^{2+}$ wave propagation. Cell Death Differ 2004; 11: $1265-1276$

37. Oakes SA, Scorrano L, Opferman JT, Bassik MC, Nishino M, Pozzan T et al. Proapoptotic $\mathrm{BAX}$ and $\mathrm{BAK}$ regulate the type 1 inositol trisphosphate receptor and calcium leak from the endoplasmic reticulum. Proce Natl Acad Sci USA 2005; 102: 105-110.

38. Niessen $\mathrm{H}$, Harz $\mathrm{H}$, Bedner $\mathrm{P}$, Kramer K, Willecke K. Selective permeability of differen connexin channels to the second messenger inositol 1,4,5-trisphosphate. J Cell Sci 2000; 113 (Part 8): 1365-1372.

39. Baumgartner HK, Gerasimenko JV, Thorne C, Ferdek P, Pozzan T, Tepikin AV et al. Calcium elevation in mitochondria is the main $\mathrm{Ca}^{2+}$ requirement for mitochondrial permeability transition pore (mPTP) opening. J Biol Chem 2009; 284: 20796-20803.

40. Sims CE, Allbritton NL. Metabolism of inositol 1,4,5-trisphosphate and inositol 1,3,4,5 tetrakisphosphate by the oocytes of Xenopus laevis. J Biol Chem 1998; 273: 4052-4058. 